Andrew B. Moynihan

University of Limerick
Eric R. Igou

University of Limerick

Wijnand A. P. van Tilburg

University of Essex 
Abstract

2 Boredom is a common, unpleasant emotion that conveys meaninglessness in life and compels

3 people to escape from this adverse existential experience. Within the paradigm of existential

$4 \quad$ social psychology frameworks, previous research found that bored people endorse cultural

5 sources of meaning as compensation against this state (i.e., nostalgia, political ideologies). In

6 recent years, another form of defence against meaning threats has been identified. An existential

7 escape hypothesis relating to boredom claims that people seek to avoid meaninglessness when

8 people encounter meaning threats such as boredom. By engaging in behaviours with low self-

9 awareness, people counteract awareness of their bored and meaningless self. In this article, we

10 review the current literature on boredom in light of such acts of existential escape. We also

11 provide suggestions for future research to highlight under which circumstances people are more

12 likely to engage in existential escape and identify phenomena that need to be tested within the

13 escape process.

14 Keywords: boredom, existential escape, meaning, self-regulation, existential psychology 


\section{Existential Escape of the Bored: A Review of Meaning-Regulation Processes Under}

\section{Boredom}

Boredom is a common, unpleasant experience (Chan et al., 2018; Van Tilburg \& Igou, 2017a) and refers to a distinct emotional state with a unique set of cognitions, feelings, and motivations (Goldberg, Eastwood, LaGuardia, \& Danckert, 2011; Van Tilburg \& Igou, 2012).

Boredom is characterised by low or mixed levels of arousal (Leary, Rogers, Canfield, \& Coe, 1986; Merrifield \& Danckert, 2014) and in some cases may occur when there is a disparity between an individual's need for arousal and a lack of adequate environmental stimulation (Csikszentmihalyi, 2000; Kass \& Vodanovich, 1990; Mikulas \& Vodanovich, 1993). Boredom is also characterised by an inability to focus or engage attention (Danckert \& Merrifield, 2016; Hunter \& Eastwood, 2018). Accordingly, boredom involves experiencing restlessness and disinterest in one's predicament and motivates people to pursue more satisfactory goals (Barbalet, 1999; Eastwood, Frischen, Fenske, \& Smilek, 2012; Leong \& Schneller, 1993). Based on this notion, boredom has been portrayed as an unpleasant but ultimately functional emotion as it informs people of the mundaneness of their current circumstances and motivates people to escape from it in the pursuit of more worthwhile activity (e.g., Elpidorou, 2014, 2018a, 2018b, 2020; see also Bench \& Lench, 2013, 2019; Van Tilburg \& Igou, 2011, 2017a).

A key distinguishing feature of boredom is that it marks an appraised lack of meaning in one's present situation or even life in general (Chan et al., 2018; Fahlman, Mercer, Gaskovski, Eastwood, \& Eastwood, 2009; Van Tilburg \& Igou, 2012, 2017a). Bored people interpret their situation as purposeless and feel dissatisfied, restless, and unchallenged. In response, boredom serves the self-regulatory function of directing people's cognitions and behaviours toward addressing the lack of meaning at hand by pursuing more meaningful, satisfactory, or stimulating 
1 activity (Elpidorou, 2014, 2018b, 2020; Van Tilburg \& Igou, 2012, 2017a). In accordance with

2 research on meaning-regulation (e.g., Heine, Proulx, \& Vohs, 2006), boredom promotes the use

3 of symbolic (i.e., cultural) sources of meaning as compensation for meaninglessness, such as

4 favouring one's in-group and derogating an out-group (Van Tilburg \& Igou, 2011), inspiring

5 pro-social tendencies (Van Tilburg \& Igou, 2017b), engaging in nostalgic reverie (Van Tilburg,

6 Igou, \& Sedikides, 2013), affirming one's own political ideologies (Van Tilburg \& Igou, 2016)

7 and affirmation of heroes (Coughlan, Igou, Van Tilburg, Kinsella, Ritchie, 2017). Meaning

8 systems such as religion can also serve as a buffer against boredom experiences (Van Tilburg,

9 Igou, Maher, Moynihan, \& Martin, 2019).

\section{Existential Escape Hypothesis}

Defences against the meaninglessness of boredom are not limited to engagement with

12 sources of meaning, however. An alternative form of defence is based on one principle course of

13 action in motivation and self-regulation: avoidance (e.g., Folkman, Lazarus, Dunkel-Schetter,

14 DeLongis, \& Gruen, 1986) and the avoidance of unpleasant thoughts and feelings in particular

15 (e.g., Baumeister, 1991). In existential psychology literature, Wisman (2006) proposed the

16 defence of 'losing the self' by engaging in behaviours that prevent adverse self-awareness

17 (Baumeister, 1988, 1990, 1991). By doing so, people can reduce awareness of a threat to

18 meaning in life as an alternative to affirming worldviews or bolstering the self to deal with

19 meaninglessness. According to this existential escape hypothesis, people may also use

20 behaviours not specific to culture but that are more evolutionarily and developmentally more

21 basic (e.g., eating, drinking, sex, anonymity in groups) to deal with existential anxieties. Wisman

22 calls these behaviours presymbolic as people can enact them with little involvement of the 
1 symbolic capacities needed in the more advanced cultural world. Typically, hedonic and some

2 interpersonal behaviours function as presymbolic resources.

To delineate this point, Wisman (2006) notes that humans have skills that allow them to

4 survive in the physical and primitively social world, such as eating, reproducing, and being lazy

5 to conserve energy. Wisman proposes that in the early stages of human civilisation, humanity

6 was aware of some meaning threats such as one's mortality (e.g., Greenberg, Pyszczynski, \&

7 Solomon, 1997). Accordingly, these presymbolic mechanisms may have been modified through

8 evolution to help people cope with meaning threats when symbolic capacities to regulate

9 meaning were not developed or available (Kesebir \& Pyszczynski, 2012; see also Koole, Sin, \&

10 Schneider, 2014; Tai, Zheng, \& Narayanan, 2011).

Within the literature referring to escape processes, Wisman (2006) proposes that people

12 regulate self-awareness to avoid unpleasant existential concerns (e.g., challenges to meaning in

13 life). Presymbolic mechanisms are assumed to operate by reducing objective self-awareness and

14 thereby reducing attention to the meaning threat the self is facing. This contention builds on the

15 notion that the perception of meaning threats is founded on an awareness of one's own attributes

16 and needs (Kim, Seto, Davis, \& Hicks, 2015; Sedikides \& Skowronski, 1997, 2003; Skowronski

$17 \&$ Sedikides, 2019). An outline of this existential escape process is presented in Figure 1.

Objective self-awareness theory (Duval \& Wicklund, 1972) posits that directing attention

19 towards the self initiates an evaluative process in which one's current state on a salient

20 dimension is compared with ideal standards for that dimension (e.g., Carver, 1975; Duval,

21 Duval, \& Mulilis, 1992; Gollwitzer \& Wicklund, 1985; Phillips \& Silvia, 2005; Silvia \& Duval,

22 2001; Wicklund \& Duval, 1971). Discrepancies between the actual (e.g., meaningless) and ideal

23 self (e.g., meaningful) are perceived by people experiencing meaning threats (Arndt, Greenberg, 
1 Simon, Pyszczynski, Solomon, 1998; Silvia, 2001; Taubman Ben-Ari \& Noy, 2010). These

2 discrepancies arouse negative feelings and may motivate people to avoid self-awareness (Duval

3 \& Wicklund, 1972). By abandoning the facility needed to perceive meaning threats (Kim et al.,

$4 \quad$ 2015; Sedikides \& Skowronski, 2003), escaping self-awareness could be an appropriate means to

5 counteract the meaninglessness signaled by threats such as boredom. Wisman (2006) proposes

6 that this existential escape process involves engaging in behaviours that dampen the adverse self-

7 awareness needed to perceive meaning threats (e.g., hedonic food consumption; Hirschberger \&

8 Ein-Dor, 2005; alcohol consumption; Ein-Dor et al., 2014, Hull, 1981, Wisman, Heflick, \&

9 Goldenberg, 2015; anonymity in groups; Wisman \& Koole, 2003).

In a similar context regarding objective self-awareness (Duval \& Wicklund, 1972), high

11 self-awareness can promote attributions of failure to the self (Duval \& Silvia, 2002; Silvia \&

12 Duval, 2001) but also defensive, external attributions for negative events in people's lives. When

13 people are discrepant from a standard, they make attributions for the cause of the discrepancy

14 and appraise the likelihood that the discrepancy can be reduced. If people believe that the

15 discrepancy can be reduced, people may attribute failure internally and attempt to change the

16 self. However, if the discrepancy cannot be reduced, such as if the discrepancy is too large or

17 unattainable, people can attribute failure externally to another cause as a defence mechanism.

18 This latter strategy promotes attempts to avoid self-awareness and reminders of the discrepancy

19 between the self and ideal standards (Silvia \& Duval, 2001).

\section{Self-Esteem and Existential Escape}

In relation to self-awareness and the attribution of unmet standards to the self, self-esteem

22 is a resource that people also use to defend against threats to meaning in life (Heine et al., 2006;

23 Greenberg et al., 1986). Self-esteem is in part a culturally-based construction that entails viewing 
1 oneself as living up to specific standards of value that are derived from culture (Arndt \&

2 Goldenberg, 2010). These standards, embedded in cultural worldviews, imbue the world with

3 meaning (Heine et al., 2006). Major existential psychological frameworks such as the meaning

4 maintenance model (Heine et al., 2006) presuppose that individuals are motivated to achieve

5 self-esteem among other core needs so as to highlight one's value based on one's adherence to

6 cultural worldviews and thereby protect oneself from existential anxiety (e.g., Dechesne,

7 Pyszczynski, Arndt, Ransom, Sheldon, Van Knippenberg, \& Janssen, 2003). As a result, people

8 who can affirm self-esteem, with available and salient resources, may not address perceived

9 meaninglessness by existential escape but instead by adhering to valued, cultural worldviews

10 (e.g., Ferraro, Shiv, \& Bettman, 2005; Taubman Ben-Ari \& Findler, 2005). For example,

11 Wisman et al. (2015) found that under mortality salience (a meaning threat), people low in self-

12 esteem had lower scores on measures of private self-awareness. Participants with low self-

13 esteem also scored lower on measures of implicit self-activation and were more likely to choose

14 to write about others than themselves. Finally, Wisman et al. (2015) found that participants with

15 low self-esteem consumed greater quantities of alcohol as an escape under mortality salience

16 (Landau \& Greenberg, 2006 also showed that participants with high self-esteem pursued more

17 risky decisions in attempts to achieve excellence despite substantial risk of failure. In contrast,

18 people with low self-esteem were more risk averse). Accordingly, Wisman (2006) proposed that

19 people with strong, coherent worldviews manage meaning threats by worldview defence,

20 whereas if people feel incompetent to live up to or become increasingly aware of self-

21 discrepancies set by these cultural norms, they may enact escape behaviour. Therefore, Wisman

22 et al. (2015) reason that people with low self-esteem lack the means to bolster the self as a 
1 defence and are more likely to engage in existential escape in response to meaning threats such

2 as boredom (see also Aspinwall \& Taylor, 1993; Reed \& Aspinwall, 1998).

3 Existential Escape: An Advancement From Terror Management Theory

$4 \quad$ Wisman (2006) developed the existential escape hypothesis, in part, to advance terror

5 management research. Terror management theory (Greenberg, Pyszczynski, \& Solomon, 1986)

6 is based on the uniquely human capacity for self-awareness and premises that humans face a

7 unique existential dilemma: People are biologically and psychologically programmed to live but

8 they are also cognitively sophisticated enough to realise that they will eventually die. Objective

9 self-awareness theory has informed a lot of research in social psychology (Silvia \& Duval,

10 2001), including terror management theory (Arndt et al., 1998). Mortality salience can be

11 interpreted as the recognition of a discrepancy between the self as a finite creature and people's

12 instincts to want to live (Arndt et al., 1998). This underlying assumption of terror management

13 theory (Greenberg et al., 1997) is consistent with the tenets of objective self-awareness theory

14 (Duval \& Wicklund, 1972); directing attention towards the self initiates an evaluative process in

15 which one's current state on a salient dimension is compared with ideal standards. Indeed, high

16 levels of self-awareness can serve as an internal death reminder and highlight one's vulnerability

17 (Taubman Ben-Ari \& Noy, 2010). That is, awareness of one's existence also relates to the

18 recognition that one will inevitably die and cease to exist (Silvia, 2001). If the estimated

19 probability of reducing that discrepancy is low, people will be motivated to abandon the situation

20 that promotes self-focused attention. As a result, self-awareness facilitates the fear of death and

21 heightens the existential anxiety it arouses.

Thus, the potential for terror in the face of this frightening contradiction must be

23 managed. Terror management theory specifies culture as the primary instrument though which 
1

mortality salience is dealt with by imbuing life with meaning and providing standards of value against which people can attain a sense of personal value and significance. Specifically, people are posited to defend against mortality concerns with symbolic representation of the world (i.e., cultural worldviews) and the self (i.e., self-esteem derived from living up to standards of one's cultural worldview; Greenberg et al. 1986).

Within the framework of terror management theory (Greenberg et al., 1997; Greenberg, Arndt, Simon, Pyszczynski, \& Solomon, 2000; Pyszczynski, Greenberg \& Solomon, 1999), a comparable concept to existential escapes was introduced. Specifically, proximal defences were proposed to work directly to remove meaning threats from consciousness by distraction or suppression (e.g., denying vulnerability to meaninglessness; Arndt, Greenberg, Solomon, Pyszczynski, \& Simon, 1997). Consequently, people who experience mortality salience in some cases try to avoid stimuli that increase self-awareness and try to actively suppress awareness of meaning threats (Arndt et al., 1998). It was argued that these defences only provide partial relief as the effects of these defences are temporary (Arndt \& Goldenberg, 2010). Existential escapes according to Wisman (2006) extend beyond distraction or suppression by allowing people to cope effectively with meaning threats (Goldenberg, Arndt, Hart, \& Brown, 2005; Heatherton, Polivy, Herman, \& Baumeister, 1993; McGregor, Nash, Prentice, Hirsh, \& Inzlicht, 2012). Further, unlike proximal defences, Wisman et al. (2015) found that existential escape behaviours (i.e., alcohol consumption) have also been shown to occur at the distal (i.e., non-conscious) level of awareness of meaning threats. Wisman also notes that these hedonic and interpersonal behaviours have previously been explained in terms of self-esteem enhancement or worldview defence. However, some studies showed that individuals who experience meaning threats occasionally engage in risky, hedonic behaviours even when their own beliefs or health are at 
1 stake (Ferraro et al., 2005; Goldenberg et al., 2005; Taubman Ben-Ari \& Findler, 2005) or might

2 affiliate with groups who have worldviews contrary to one's own (Wisman \& Koole, 2003). In

3 sum, when meaning threats are salient, individuals might engage in certain hedonic or

4 interpersonal behaviours to dampen the meaninglessness signaled by meaning threats and

5 captured by self-awareness (e.g., Baumeister, 1991; Heatherton \& Baumeister, 1991; Wisman,

6 2006). Hence, reducing self-focus may also reduce perceptions of meaninglessness (e.g., Arndt

7 et al., 1998; Silvia, 2001; Taubman Ben-Ari \& Noy, 2010) and help people to escape from

8 meaning threats including boredom.

\section{The Current Review}

This review assesses the current state of existential escape research on boredom. We

11 accumulate a body of evidence from hitherto loosely related studies to suggest that boredom,

12 when interpreted as a meaning threat, can promote responses that are geared towards avoiding

13 the self and the associated conflict. This is complementary to established research, showing that

14 affirming cultural worldviews might be alternative means to deal with boredom and its

15 characteristic sense of meaninglessness (e.g., Van Tilburg \& Igou, 2011, 2016). Our review

16 allows us to understand some of the underlying mechanisms that explain boredom's relationships

17 with hedonic and interpersonal behaviours using existential psychological perspectives.

18 Previously, boredom has been linked with impulse control deficits (Leong \& Schneller, 1993),

19 unhealthy and binge eating (Cleobury \& Tapper, 2014; Stickney \& Miltenberger, 1999), and

20 risk-taking (e.g., dangerous driving; Kass, Beede, \& Vodanovich, 2010; K1lıç, Van Tilburg, \&

21 Igou, 2020), among others (see Elpidorou, 2018a). By assessing different studies, we outline the

22 key roles of perceptions of meaninglessness as an underlying explanatory variable and self-

23 awareness as a qualifier of these effects when they are forms of existential escape. More broadly, 
1 we contribute to boredom's place as a meaning threat within existential psychology, considering that some of boredom's effects (i.e., on hedonic and interpersonal behaviours) have previously been explained by other, complementary factors (e.g., trying to engage attention, Hamilton, Haier, \& Buchsbaum, 1984; seeking challenge or sensation; Dahlen, Martin, Ragan, \& Kuhlman, 2004; Mercer \& Eastwood, 2010). Accordingly, we focus on boredom as a meaning threat in our review, given the lack of a synthesis on this research topic, in comparison to reviews on boredom using other perspectives (e.g., attentional theories, Eastwood et al., 2012).

The value of this review for the field of social psychology is that it provides a discussion on another type of defence against meaning threats than what has already been extensively investigated in previous social psychological research (e.g., Pyszczynski et al., 1999). The existential escape hypothesis (Wisman, 2006) provides a viable framework to expand on earlier social psychological models such as terror management theory (e.g., Greenberg et al., 1997) and the meaning maintenance model (Heine et al., 2006). Wisman (2006) notes that the existential escape hypothesis provides a framework that can account for several anomalies within terror management theory (Greenberg et al., 1997; Wisman \& Koole, 2003) and synthesises a wide range of theoretical perspectives into one comprehensive framework of existential selfregulation. Furthermore, the majority of previous research on existential escape used mortality salience as a candidate meaning threat (e.g., Wisman et al., 2015; Wisman \& Koole, 2003; Wisman \& Shrira, 2015). Based on meaning threats shared foundation of meaninglessness (Heine et al., 2006), the processes of existential escape (Wisman, 2006) may also be applicable to how people deal with other meaning threats such as boredom (Van Tilburg \& Igou, 2017). Boredom is a common, everyday emotion (Chan et al., 2018) that is associated with many interpersonal, social, and health consequences (Elpidorou, 2018a), indicating that boredom is a 
worthwhile area of study for social psychologists, among others. As many of boredom's correlates can be conceptualised as acts of escape relating to the self (e.g., Heatherton \& Baumeister, 1991; Twenge, Catanese, \& Baumeister, 2003) and given that a review on boredom research using the existential escape hypothesis (Wisman, 2006) framework is lacking, this review is merited and timely.

In our review, we begin by briefly discussing early research that used the framework of

7 the existential escape hypothesis regarding mortality salience. Next, we discuss how boredom

8 was incorporated into the field, based on its links with behaviours that involve low self-

9 awareness (e.g., Baumeister, DeWall, Ciarocco, \& Twenge, 2005; Twenge et al., 2003). We outline our research on food consumption and impulsiveness as means of escaping from

11 boredom, while highlighting the roles of adverse self-awareness and meaninglessness in these

12 relationships. Afterwards, we present ideas for alternative means of existential escape that might 13 occur in response to boredom (e.g., sex, conformity, 'dark' flow). Finally, we present boundary 14 conditions under which the existential escape effects of boredom likely occur, we discuss the 15 long-term effectiveness of escape as a coping strategy, and we highlight some practical applications of this field. We believe that appraising and discussing existential escape research

17 on boredom in this way provides a thorough and critical synthesis of the present state of

18 research, offering good directions for future research and practical applications.

\section{Existential Escape From Boredom}

Early research on the existential escape hypothesis (Wisman, 2006) was conducted using

21 mortality salience as a candidate meaning threat. Among the findings from this research were

22 that people who are aware of their mortality are more likely to sit with others, as opposed to

23 sitting alone. Critically, this occurred even if the group members threatened participants' 
1 worldviews, a source of symbolic meaning (Wisman \& Koole, 2003). As part of a replication study, Wisman and Shrira (2006) further noted that participants were unwilling to increase contact with confederates. That is, participants sought to lose themselves in a group rather than

4 defend or attack their own worldviews (i.e., use their symbolic self-awareness). Later, Wisman breakdown of fatty acids in the decaying tissue of dead bodies, can function as a chemosensory warning signal, activating threat management responses (i.e., walking away quicker from experimental settings; completing more escape-related word-stem completion tasks). Finally,

9 Wisman et al. (2015) found that these escape behaviours in response to mortality salience were more likely among people low in self-esteem and could be exhibited through behaviours such as

11 less implicit self-activation, choosing to write about others rather than the self, and alcohol 12 consumption. Bored people similarly have a strong desire to escape from their unpleasant

14 circumstances (Elpidorou, 2014, 2020). Accordingly, our research on existential escape was 15 conducted using boredom as a meaning threat. Boredom is associated with several hedonic and 16 impulsive behaviours such as unhealthy eating (Crockett, Myhre, \& Rokke, 2015), aggression

17 (Dahlen et al., 2004; Rupp \& Vodanovich, 1997; Van Tilburg, Igou, Maher, \& Lennon, 2019), 18 substance abuse (Lee, Neighbors, \& Woods, 2007), unsafe driving (Dahlen, Martin, Ragan, \& 19 Kuhlman, 2005), pathological gambling (Blaszczynski, McConaghy, \& Frankova, 1990), and 20 sexual behaviours (Gana, Trouillet, Martin, \& Toffart, 2001; see also Elpidorou, 2018a).

21 Interestingly and in line with existential escape theorising, engaging in stimulating, hedonic 22 activities while bored (e.g., Kass \& Vodanovich, 1990; Mercer \& Eastwood, 2010; Mikulas \& 
1 Vodanovich, 1993) may serve the function of avoiding meaninglessness and adverse self-

2 awareness (e.g., Seib \& Vodanovich, 1998) associated with boredom.

\section{Consumption}

We conducted the first study that investigated the effect of boredom on existential escape behaviours, specifically unhealthy eating (Moynihan et al., 2015). Previous research on mortality

6 salience by Hirschberger and Ein-Dor (2005) found that participants whose mortality was made

7 salient subsequently consumed more candies. Furthermore, this increase in consumption

8 effectively buffered against mortality salience; subsequent efforts to regulate meaning through

9 symbolic means (e.g., cultural adherence) were non-existent. Similarly, Ferraro et al. (2005)

10 found that participants who had low self-esteem in a certain respect (i.e., their physical

11 appearance) decided to eat a more indulgent, unhealthy snack (chocolate cake) than a healthier

12 alternative (fruit salad) following mortality salience. Boredom has also been linked with

13 unhealthy and emotional eating in previous research (Cleobury \& Tapper, 2014; Crockett,

14 Myhre, \& Rokke, 2015; Koball, Meers, Storfer-Isser, Domoff, \& Musher-Eizenman, 2012), yet,

15 to our knowledge, had not been interpreted within the existential escape model previously. Since

16 eating distracts people from unpleasant self-awareness (Heatherton \& Baumeister, 1991;

17 Heatherton, Striepe. \& Wittenberg, 1998; Wheeler, Adams, \& Keating, 2001), we investigated

18 whether eating functions as a means of existential escape from boredom in our first set of studies

19 on boredom and the existential escape hypothesis (Wisman, 2006).

In our first study (Moynihan et al., 2015), we used a diary procedure to examine people's

21 state boredom in their everyday lives and whether increases in state boredom predicted increased

22 food intake. In Study 1, 33 people from Limerick city, Ireland completed a pencil and paper-

23 based diary study over 7 days. Initially, participants were asked to record their demographics, 
1 including their height and weight, and a shortened measure of the 'boredom proneness scale'

2 (Gordon, Wilkinson, McGrown, \& Jovanoska, 1997) to assess their individual proclivities to

3 experience boredom. The participants also completed the 'positive and negative affect scale'

4 short-form (Watson, Clark, \& Tellegen, 1988). Over the next week, participants completed three

5 items each evening that assessed how bored and stressed participants felt during each day, as

6 well as how enjoyable they found each day. The participants kept track of their daily food and

7 drink intake using the 7-days EPIC-Norfolk diary (Bingham et al., 2001). This highly detailed

8 food diary consists of a booklet with separate sections for participants to record their daily food

9 and drink consumption. Participants were requested to be as detailed as possible in their records

10 and the booklets contained colour pictures of various food and drink types and amounts to aid

11 their assessment of the portions they consumed. Following our data collection, we decoded the

12 participants' food and drink consumption into daily amounts of energy (in kilocalories), fat,

13 carbohydrate, and protein (all in grams) using an aid by McGuire and Beerman (2007) to

14 calculate the food and drinks' compositions.

Our week-long diary study showed that daily state boredom predicted increased

16 kilocalorie, fat, carbohydrate, and protein consumption (Table 1). Specifically, when

17 participants' level of state boredom rose by its standard deviation, participants consumed

18 approximately 100 extra kilocalories, equivalent to the energy content of a scrambled egg or

19 banana. Likewise, with every standard deviation increase in state boredom, approximately 5

20 additional grams of fat, 10 additional grams of carbohydrates, and 3 extra grams of protein were

21 consumed. These levels of consumption were equivalent to the fat content of a cookie, the

22 carbohydrate content of a packet of candies, and the protein content of a cup of mushrooms

23 respectively. These effects remained significant controlling for stress, enjoyment, and individual 
1 differences in boredom proneness, positive affect, negative affect, and body mass index.

2 Therefore, our hypothesis that state boredom predicts increased consumption was supported in

3 this diary study, offering real-life empirical evidence of the existential escape process regarding

4 boredom.

5 Next, we complemented our diary study by testing the causal relationship between state

6 boredom and eating through lab experimentation. Specifically, we investigated if the adverse

7 state of self-awareness that bored people experience motivates them to eat as a means of

8 existential escape. We predicted that people high in dispositional self-awareness, who are

9 particularly prone to introspection, would be more likely to engage in existential escape in

10 response to boredom. Here, we manipulated participants' state boredom and subsequently

11 measured their food preferences at different levels of objective self-awareness. Seventy-nine

12 participants from the University of Limerick, Ireland were recruited. First, our participants

13 completed a measure of objective self-awareness using Fenigstein, Scheier, and Buss's (1975)

14 'self-consciousness scale.' Next, we randomly assigned our participants to one of two conditions

15 of a between-subjects experiment. Our boredom manipulation consisted of a simple puzzle in

16 which participants had to connect different objects while adhering to basic rules. In the low

17 boredom condition, several pictures of cows and chickens were depicted and needed to be

18 connected by drawing a line to a trough or coop, respectively. As part of our instructions, 'paths'

19 or 'canals' in the puzzle were not to be crossed and there was a limit to the amount of animals

20 that could be connected to each trough or coop. In the high boredom condition, the puzzle was

21 identical, except that the cows, chickens, troughs, and coops were replaced with circles,

22 rectangles, triangles, and squares, respectively. A pilot test confirmed that the task involving the

23 shapes was significantly more boring than the puzzle with the farm animals. After completing 
1 the boredom manipulation, participants indicated their desire to snack after completing the

2 puzzle as well as their wish to eat something healthy.

Supporting our hypothesis, we found that the high (vs. low) boredom task increased

4 participants' desire to snack as opposed to eating something healthy, especially among

5 participants high in objective self-awareness. Specifically, we found that participants' desire to

6 snack under high levels of boredom was more pronounced for people high in objective self-

7 awareness. Yet, no significant association was found between objective self-awareness and

8 snacking desire among those in the low boredom condition (Figure 2). There was no significant

9 interaction between the boredom manipulation and objective self-awareness on participants'

10 desire to eat something healthy. In sum, our results indicated that boredom fosters the desire to

11 snack, rather than eat healthily, especially among those high in objective self-awareness. These

12 findings were in line with the tenets of the existential escape hypothesis (Wisman, 2006).

13 Boredom also encourages people to seek sensation (e.g., Dahlen et al., 2004; Kass \&

14 Vodanovich, 2000). Consistent with existential escape theorising, 'exciting' food may be a

15 potent distraction from boredom and its inherent meaninglessness by providing an intense

16 appearance or taste (see Craeynest, Crombez, Koster, Haerens, \& De Bourdeauhuij, 2008;

17 Hirschberger \& Ein-Dor, 2005; McGregor et al., 2012). Accordingly, in our final study

18 (Moynihan et al., 2015; Study 3), we tested whether high (vs. low) levels of boredom increased

19 the participants' consumption of unhealthy foods (i.e., candies) but also the consumption of more

20 exciting, healthy foods (cherry tomatoes) among people high in objective self-awareness. Hence,

21 we investigated whether the sensation seeking aspect of boredom also promotes eating healthy

22 and exciting foods as a means of existential escape, especially among people high in objective

23 self-awareness. 
Forty-four students initially completed the 'self-consciousness scale' as a measure of objective self-awareness (Fenigstein et al., 1975). Subsequently, our participants were randomly assigned to one of two conditions of a between-subjects experiment. The participants were either manipulated to be bored by watching a video on fish farming or instead watched a sad video on dolphin abuse in the control condition. Before the film started, participants were presented with three separate bowls of candies (an exciting, unhealthy food), cherry tomatoes (an exciting, healthy food), or crackers (an unexciting, healthy food). In a pilot test, fourteen participants rated the crackers as significantly less exciting than the candies and the cherry tomatoes, whereas there was no significant difference in how exciting the participants rated the candies and cherry tomatoes. Prior to watching the film, participants were told that they could eat as many or as few of the foods provided during the study. After watching the movies, our participants reported how boring and sad the films were and how bored and sad they felt.

In line with our hypothesis, we found that participants in the boredom condition were significantly more likely to eat greater quantities of candy, that is exciting unhealthy food, at higher levels of self-awareness, consistent with existential escape theorising. This was in contrast to participants who had lower levels of self-awareness in the boredom condition. Further, the effects did not extend to a control condition in which participants watched a sad video on dolphin abuse. At the same time, participants manipulated to be bored by watching the video on fish farming were also significantly more likely to eat greater quantities of tomatoes, an exciting, healthy food at higher levels of self-awareness, consistent with existential escape theorising. This was in contrast to participants who had lower levels of self-awareness in the boredom condition. Further, the effects did not extend to a control condition in which participants watched the sad video on dolphin abuse. These results are displayed in Figures 3a and 3b. Critically, this increase 
1 in eating did not extend to unexciting, healthy food (crackers) in the boredom condition. In sum,

2 our studies showed that boredom, a threat to meaning in life (Van Tilburg \& Igou, 2017a),

3 promotes eating as a means to escape from adverse self-awareness, associated with that meaning-

4 threat. Our findings were consistent with the tenets of the existential escape hypothesis (Wisman,

5 2006) and incorporated both boredom and eating into the existential escape framework.

6 Specifically, boredom promotes eating unhealthy foods such as during snacking as a means of

7 existential escape but eating exciting, healthy foods are also functional, given that boredom also

8 promotes sensation-seeking.

\section{$9 \quad$ Impulsiveness}

In other existential psychological research on consumption, Friese and Hoffman (2008)

11 showed that mortality salience increased eating as a function of higher scores on an implicit

12 measure of impulsiveness (the implicit association test; Karpinski \& Steinman, 2006). Some

13 scholars speculated that these kinds of eating behaviours and other hedonic acts may be

14 expressions of the impulsiveness bred by meaning threats such as boredom (e.g., Gerritsen,

15 Toplak, Sciaraffa, \& Eastwood, 2014). Indeed, recent research by Kılıç et al. (2020) highlighted

16 that both trait and state boredom are associated with increased risk-taking across various

17 domains (e.g., health and safety, recreational, gambling). Further, an interaction was noted in that

18 research such that the relationship between self-control and risk-taking was reduced at higher

19 levels of boredom, suggesting that boredom might involve risk-taking by virtue of reducing

20 people's capacity or willingness to exercise self-control. Following our research on boredom and

21 eating, we proposed that impulsiveness in response to boredom (Mercer-Lynn, Flora, Fahlman,

22 \& Eastwood, 2013; Watt \& Vodanovich, 1992) partly stems from people's attempts to escape

23 from meaninglessness (Moynihan, Igou, \& Van Tilburg, 2017a). In this regard, we argued that 
1 the effect of boredom on impulsiveness would be stronger for people with a high (vs. low) self-

2 awareness disposition.

To test these hypotheses, we initially conducted two cross-sectional studies. In our first

4 study, 100 participants completed measures of state boredom (Van Tilburg \& Igou, 2012),

5 perceived meaninglessness in life (Van Tilburg \& Igou, 2011), and state impulsiveness, using a

6 modified version of the Barrett impulsiveness scale - Version 11 (BIS-11; Patton, Stanford, \&

7 Barrett, 1995). In previous research, the BIS-11 was associated with behavioural expressions of

8 impulsivity such as risk-taking, aggression, alcohol consumption, drug-taking, drink driving

9 (Dahlen et al., 2004; Stanford, Greve, Boudreanx, Mathias, \& Brumbelow, 1996), binge-eating

10 (Nasser, Gluck, \& Geliebter, 2004), sensation-seeking, disinhibition, difficulty with executive

11 functioning, and problems sustaining attention (Stanford et al., 2009); it also differentiates

12 between normal and clinical samples known to be more impulsive (Patton et al., 1995). As

13 expected, we found that perceived meaninglessness significantly explained at least part of the

14 relationship between state boredom and impulsiveness (i.e., an indirect relationship; Figure 4).

Following this, we conducted a conceptual replication of this study, substituting Van

16 Tilburg and Igou's (2012) state boredom measure with the multi-dimensional state boredom

17 scale (MSBS; Fahlman, Mercer-Lynn, Flora, \& Eastwood, 2011). This is an extensively

18 validated measure of state boredom and consists of five subscales: disengagement, high arousal,

19 inattention, low arousal, and time perception. In a pilot test, we found that each subscale from

20 this measure correlated positively and significantly with perceptions of meaninglessness in life

21 (Van Tilburg \& Igou, 2012, 2017a). In our main study, consisting of 201 participants, perceived

22 meaninglessness in life was again measured using Van Tilburg and Igou's (2011) perceived

23 meaninglessness scale, while a modified version of the BIS-11 (Patton et al., 1995) served as a 
1 state measure of impulsiveness. Consistent with our first study, we found significant indirect

2 relationships between each state boredom subscale with state impulsiveness via perceived

3 meaninglessness in life (Table 2). That is, each state boredom subscale predicted increased

4 impulsiveness in response to higher perceptions of meaninglessness in life (with marginal

5 significance regarding the high arousal subscale).

$6 \quad$ For our next study, we investigated the relationships between state boredom, perceived

7 meaninglessness, and a behavioural measure of impulsivity known as a temporal discounting

8 task. A temporal discounting task is an implicit measure of impulsiveness. Temporal discounting

9 refers to the tendency for individuals to prefer immediate rewards compared to rewards received

10 after a delay, even if the magnitude of the delayed reward is larger. We recruited two hundred

11 and ninety four participants for this study from the online data collection platform MTurk. For

12 remuneration, participants received at least $\$ 0.28$. In this study, participants were initially told

13 that they would be asked to make a choice between two options on four separate occasions. As

14 part of the temporal discounting task, participants were first asked if they wanted to wait for two

15 minutes to receive an extra $\$ 0.08$ bonus that would involve completing a short task (e.g., word

16 search puzzles, writing a short story that accompanied pictures) or skip this question in exchange

17 for a $\$ 0.01$ bonus. Four trials of this task were completed in which the bonus for waiting

18 decreased by $\$ 0.02$ per trial. Afterwards, participants were asked to what extent they found the

19 two-minute waiting tasks boring and meaningless. The results supported our hypothesis that

20 boredom and perceived meaninglessness were positively associated with impulsive responses on

21 this task (i.e., participants more often skipped the tasks and declined the higher bonus payments).

Finally, we conducted a follow-up experiment. Critically, in this experiment, we included

23 a measure of trait self-awareness. Again, self-awareness highlights meaning threats' adverseness 
1 by comparing one's current (meaningless) state with ideal standards, thereby making the need to

2 deal with meaninglessness more pressing (e.g., Wisman, 2006). As a result, we predicted that the

3 effect of boredom on impulsiveness via meaninglessness would be stronger for people with a

4 high (vs. low) self-awareness disposition, in line with the existential escape hypothesis. In this

5 experiment, one hundred and sixteen participants initially completed a trait measure of self-

6 awareness (Govern \& Marsch, 2001). Our chosen scale endorsed the type of self-awareness used

7 in self-regulation and has been used in previous research to test how people deal with adverse

8 self-awareness associated with meaning threats in the context of existential escape (Wisman et

9 al., 2015). Subsequently, participants completed a reference-transcribing task to induce either

10 high or low levels of state boredom (Van Tilburg \& Igou, 2011; Van Tilburg, Igou, \& Sedikides,

11 2013). Participants in the low boredom condition transcribed, in typing, one academic reference

12 on cement, whereas participants in the high boredom condition transcribed ten references. This

13 manipulation had been validated in previous research and fosters differences in boredom but

14 does not seem to affect sadness, anger, or frustration (Van Tilburg \& Igou, 2012). After

15 completing the task, participants indicated how bored they felt (Van Tilburg \& Igou, 2011, 2012;

16 Van Tilburg et al., 2013) and also completed a measure of state meaninglessness (Van Tilburg \&

17 Igou, 2013). Finally, participants answered a state measure of the Barrett impulsiveness scale

18 (Patton et al., 1995).

As expected, our manipulation significantly induced boredom and meaninglessness;

20 participants in the high boredom condition reported significantly higher levels of state boredom

21 and meaninglessness than those in the low boredom condition. Furthermore, manipulated state

22 boredom significantly predicted increased impulsiveness via meaninglessness, replicating our

23 earlier cross-sectional findings. Finally, we tested whether self-awareness moderated the indirect 
1 relationship such that those participants who reported greater self-awareness were more likely to

2 endorse impulsiveness when bored. As expected, when our model was supplemented with self-

3 awareness as a moderator, we found significant conditional indirect effects in a moderated

4 mediation model (Figure 5). Specifically, the effect of state boredom on increased impulsiveness

5 in response to perceived meaninglessness was significant at high, but not low, levels of self-

6 awareness (Table 3). Therefore, impulsiveness in response to boredom seems to be enacted to

7 address the meaninglessness signaled by boredom, the perception of which is enhanced under

8 conditions of greater self-awareness, consistent with the tenets of the existential escape

9 hypothesis (Wisman et al., 2015).

\section{Additional Existential Escape Candidates: Sex, Conformity, and 'Dark' Flow}

Sex. Eating behaviour and impulsivity in response to boredom have been studied from the perspective that they may serve as existential escape mechanisms (Moynihan et al, 2015; Moynihan et al., 2017a). However, researchers in existential psychology have examined a range of behaviours that are enacted in response to meaning threats. An emerging area for future research is sex as a means of existential escape. Previous research, within the framework of terror management theory (Greenberg et al., 1997), showed that people experience uneasiness about the physical aspects of sex when mortality (another meaning threat) is salient. Sex can highlight the physical aspects of people's existence and people's inevitable mortality (Goldenberg, Heflick, \& Cooper, 2008; Goldenberg, Pyszczynski, McCoy, Greenberg, \& Solomon, 1999; Landau et al., 2006). As a result, people primed with mortality salience are motivated to avoid thinking and acting in ways that highlight the physical aspects of sex to obscure the links between corporeality and death (e.g. Goldenberg, Cox, Pyszczynski, 
1 Greenberg, \& Solomon, 2002; Goldenberg, Hart, Pyszczynski, Warnica, Landau, \& Thomas,

2 2006; Goldenberg, McCoy, Pyszczynski, Greenberg, \& Solomon, 2000).

However, sex may also be used as a stimulating and distracting activity in response to

4 boredom. Boredom proneness has been associated with engagement in sexual activities (e.g.,

5 masturbating, watching pornography; Gana et al., 2001), sex addictions (Chaney \& Bialock,

6 2006; Chaney \& Chang, 2005), and sexual compulsivity (Carnes, 2001; Chaney \& Burns-

7 Wortham, 2014). Sex also enables people to disassociate from uncomfortable and unpleasant

8 emotions (Paul \& Shim, 2008; Reid, Carpenter, Spackman, \& Willes, 2008; Reid, Harper, \&

9 Anderson, 2009; Taubman, 2004). Interestingly, in our recent paper (Moynihan, Igou, \& Van

10 Tilburg, 2021), we found that boredom susceptibility, associated with feelings of

11 meaninglessness in life, predicted increased interest in sexual sensation seeking and endorsing a

12 more open socio-sexual orientation (i.e., favourability towards casual, uncommitted sex).

13 Further, this relationship was statistically mediated by using sex as a coping mechanism to deal

14 with unpleasant affective states. Therefore, increased interest in hedonic forms of sex may be one

15 way to cope with boredom as a meaning threat. These findings are contrary to people's

16 unfavourable attitudes to hedonic forms of sex under mortality salience. Accordingly, we believe

17 that sex as an existential escape from the meaninglessness of boredom is an interesting and

18 important development for future research.

Conformity. Our other research on escape behaviours outlined that conformity can also

20 be used to deal with the meaning threat: disbelief in free will (Moynihan, Igou, \& Van Tilburg,

21 2019). Anonymity in social settings, exemplified through social behaviours including certain

22 types of conformity, can be used to deal with adverse self-awareness and perceptions of

23 meaninglessness, consistent with the existential escape model (Wisman \& Koole 2003; Wisman 
1 \& Shrira, 2006). Certain types of conformity are associated with dealing with stressors, withdrawing oneself and one's effort to deal with stressful circumstances (e.g., Asch, 1952), and low levels of deliberation and control (Alquist, Ainsworth, \& Baumeister, 2013; Epley \& Gilovich, 1999; see also Gudjonsson \& Sigurdsson, 2003). Furthermore, conformity engenders a loss of self-awareness in these forms (Diener, 1979; Mullen, 1991; Zimbardo, 2007).

Simultaneously, disbelief in free will diminishes the recruitment of cognitive resources for selfregulation and volition (Lynn, Muhle-Karbe, Aarts, \& Brass, 2014; Lynn, Van Dessel, \& Brass, 2013; Rigoni, Kuhn, Sartori, \& Brass, 2011; Rigoni, Pourtois, \& Brass, 2015) and lessens people's feelings of responsibility and accountability (Clark et al., 2014; Stillman \& Baumeister, 2010; Tetlock, 1983). Accordingly, the above-mentioned types of conformity can be used as a strategy to deal with feelings of diminished responsibility (Tetlock, Skitka, \& Boettger, 1989) by selecting less demanding choices (Rigoni et al., 2011), as is the case under disbelief in free will. Furthermore, previous research showed that life appears meaningless without believing in free will. Belief in free will subsumes a sense of control (an important source of meaning; Heine et al., 2006) people have over their lives (Bergner \& Ramon, 2013), their ability to set meaningful goals (Crescioni, Baumeister, Ainsworth, Ent, \& Lambert, 2016), and achieve other sources of meaning (e.g., belongingness; Moynihan, Igou, \& Van Tilburg, 2017b). As a result, in our other existential escape research, we predicted that conformity, involving low levels of self-awareness, may be one pragmatic solution to deal with disbelief in free will as a meaning threat. Indeed, Wisman and Koole (2003) previously found that conformity, involving low levels of selfawareness, can be used as a means of existential escape from mortality salience.

In our free will belief research, we showed that when people read a text by Nobel prize winning scientist Francis Crick that argued against the existence of free will, participants 
1 experienced greater threats to their free will beliefs and also to their sense of meaning in life than

2 participants who read a general essay on consciousness. In our second study, people who

3 experienced greater meaninglessness in life also reported greater tendencies to conform. In

4 particular, meaninglessness was more strongly related to types of conformity that reduced

5 people's feelings of self-awareness, consistent with the tenets of the existential escape hypothesis

6 (Wisman 2006). Finally, we found that disbelief in free will produced greater conformity in

7 response to perceptions of meaninglessness, especially for people who felt very self-aware.

8 Likewise, we believe conformity as a candidate means of existential escape from

9 meaninglessness offers interesting directions for future boredom research.

'Dark' flow. Wisman (2006) has also considered flow (Csikszentmihalyi, 2000) as a

11 form of existential escape. Flow is defined as a state "in which people are so involved in an

12 activity that nothing else seems to matter; the experience itself is so enjoyable that people will do

13 it even at great cost, for the sheer sake of doing it" (Csikszentmihalyi, 1990, p. 4). Critically, the

14 experience also involves a loss of self-consciousness (Csikszentmihalyi, Abuhamdeh, \&

15 Nakamura, 2005). In recent years, some researchers have termed certain instances of flow "dark

16 flow," given the state's possible negative consequences (e.g., Dixon et al., 2019). "Dark flow"

17 also refers to a highly-absorbing, enjoyable experience (Dixon et al., 2017). Yet, the loss of self-

18 reflection and underestimation of risk experienced during "dark flow" may lead to greater

19 engagement in high risk, immersive, yet enjoyable activities such as problem gambling (Dixon et

20 al., 2014) and risky sports (Partington, Partington, \& Olivier, 2009; Schüler \& Nakamura, 2013).

21 Similarities can be noted between "dark flow" and some forms of existential escape. Both

22 concepts refer to means of coping with painful emotional experiences and absorbing, immersive,

23 pleasurable activities that draw attention away from the self. Both concepts may also carry 
1 substantial risk and promote addiction (e.g., Csikszentmihalyi, 2002; see also Baumeister, 1988;

2 Wisman et al., 2015). Hence, considering the role of "dark flow" within the existential escape

3 process may be an interesting extension for future research.

$4 \quad$ Strategies and Boundary Conditions

Some researchers have questioned under which conditions different strategies (e.g.,

6 escaping or bolstering the self) are selected to defend against meaning threats (e.g., Arndt \&

7 Goldenberg, 2010; Kesebir \& Pyszczynski, 2012; Wisman et al., 2015). Within the broader

8 coping literature, escape-avoidance strategies tend to be used more in high-stake conditions (e.g.,

9 threats to self-esteem) and in situations which people appraise as having to be accepted due to a

10 lack of control, people feel over certain stressors (i.e., a form of emotion-focused coping;

11 Folkman et al., 1986). For instance, the terror management literature suggests that people

12 initially seek to avoid meaning threats (e.g., by distraction, suppression) when they first become

13 consciously aware of them (Arndt et al., 1997; Greenberg et al., 2000). Also, people with low

14 self-esteem are more likely to become preoccupied with distressing emotions, which makes them

15 more likely to disengage from reality when they feel uneasy and incapable of dealing with

16 meaning threats (Carver, Scheier, \& Weintraub, 1989; Gudjonsson \& Sigurdsson, 2003).

\section{Self-Esteem}

18 By its nature of serving as a resource (e.g., Aspinwall \& Taylor, 1993, 1997; Reed \&

19 Aspinwall, 1998), people can use self-esteem psychologically to defend against meaning threats

20 (Heine et al., 2006; Greenberg et al., 1986). Those who can affirm self-esteem, with available

21 and salient resources, may not address perceived meaninglessness by escape (e.g., Ferraro et al.,

22 2005; Taubman Ben-Ari \& Findler, 2005; Wisman et al., 2015). Wisman (2006) proposed that

23 people with strong, coherent worldviews manage meaning threats by worldview defence, 
1 whereas if people feel incompetent to live up to or become increasingly aware of self-

2 discrepancies set by these cultural norms, they may enact escape behaviours. For instance, if

3 people become aware of a meaning threat and available worldview defences relate to insecure

4 aspects of the self, they may instead engage in existential escape if they have the opportunity to

5 avoid this distress (e.g., Heatherton et al., 1993; Heatherton et al., 1998; Wheeler et al., 2001).

6 Indeed, people who lack self-esteem or feel insecure in a certain respect (e.g., their physical

7 appearance) do not use those resources under meaning threats (e.g., Goldenberg et al., 2000), in

8 particular, if they have the opportunity to escape this aversive state (Goldenberg et al., 2005).

9 Wisman et al. (2015) reason that people with low self-esteem lack the means to bolster

10 the self as a defence. Addressing the meaninglessness captured by self-awareness through escape

11 may be easier than affirming self-esteem as the latter would require a sense of adverse self-

12 awareness in the context of meaning threats (e.g., Wisman \& Koole, 2003). Accordingly,

13 Wisman et al. suggest that people with high self-esteem are more likely to strive to reduce the

14 discrepancy between their current (e.g., meaningless) selves and their standards (e.g.,

15 meaningful), whereas people low in self-esteem are more likely to engage in existential escape.

\section{Self-Objectification}

In conjunction, variables such as self-objectification might have an impact on escape acts

18 such as consumption in response to boredom. Self-objectification refers to the extent to which

19 people measure their self-worth by evaluating their physical appearance against a culture's set

20 standards (Fredrickson, Roberts, Noll, Quinn, \& Twenge, 1998). Self-objectification has

21 frequently been associated with low self-esteem (Fredrickson \& Roberts, 1997). Following the

22 reasoning outlined above, people who are bored and who score highly on measures of self-

23 objectification would be assumed to act more unhealthily (e.g., by increased consumption), as 
1 drawing attention to an insecure aspect of the self, in the context of meaning threats, may

2 motivate people to escape from this adverse state. This is because people who self-objectify may

3 feel insecure in their capacity to achieve cultural standards of value (Fredrickson et al., 1998).

$4 \quad$ This theorising is consistent with previous self-objectification research showing that people who

5 scored high on self-objectification consumed more under ego distress (e.g., Heatherton, Herman,

6 \& Polivy, 1991; Heatherton et al., 1993). In our pilot data (Moynihan, Igou, \& Van Tilburg,

7 2017c), we found a significant interaction between a boredom manipulation (Van Tilburg \&

8 Igou, 2011), self-awareness (Govern \& Marsch, 2001), and self-objectification (Fredrickson et

9 al., 1998) on increased endorsement of unhealthy behaviours. Specifically, participants who were

10 manipulated to be bored and who scored highly on measures of self-awareness and self-

11 objectification were more likely to act unhealthily. This result was consistent with previous

12 research (e.g., Heatherton et al., 1991; Heatherton et al., 1993). Thus, boredom may lead

13 insecure, self-objectifying people to relinquish their impulses and engage in distracting, hedonic

14 behaviour to address the perceived meaninglessness of and adverse self-awareness associated

15 with boredom (Heatherton et al., 1991; Heatherton et al., 1993; Heatherton et al., 1998; Polivy,

16 Heatherton, \& Herman, 1988).

\section{Body-Esteem}

Additionally, the effect of body-esteem, defined as people's satisfaction with their bodies

19 that meet standards of value, on acts such as consumption or sex in response to boredom could

20 also be investigated as a potential moderator (Franzoi \& Shields, 1984). In earlier research,

21 Ferraro et al. (2005) found that females under mortality salience with higher body-esteem chose

22 to eat healthier produce to bolster the self. Regarding existential escape, boredom might interact

23 with high body-esteem ratings to predict decreased unhealthy consumption at higher levels of 
1 body-esteem (see also Carver \& Scheier, 1982; Goldenberg et al., 2000) and thereby promote the

2 use of symbolic resources to deal with existential anxiety (see also Taubman, Florian, \&

3 Mikulincer, 1999). Indeed, in our pilot data (Moynihan, Igou, \& Van Tilburg (2017d), we found

4 that a boredom manipulation (Van Tilburg \& Igou, 2011) significantly interacted with body-

5 esteem ratings (Franzoi \& Shields, 1984) to predict decreased unhealthy consumption at higher

6 levels of body-esteem (see also Carver \& Scheier, 1982; Goldenberg et al., 2000). Therefore, the

7 effects of body-esteem on hedonic responses to meaning threats may also extend to boredom.

8 Simultaneously, Goldenberg et al. (2000) also found that people find the physical aspects of sex

9 more appealing in response to mortality salience if they are able to affirm their body esteem to

10 defend against that meaning threat. As a result, it is likely that people who score highly on body

11 esteem would be less likely to engage in certain forms of escape (e.g., consumption) or

12 alternatively may do so as a symbolic gesture to bolster the self (e.g., physical aspects of sex).

\section{Coping Styles}

An important direction for future research is to investigate the link between existential escape strategies and coping responses in general (see Arndt \& Goldenberg, 2010; Crockett et al., 2015). Coping has two major functions: to regulate stressful emotions (emotion-focused

17 coping) and alter the troubled person-environment relationship causing the distress (problem-

18 focused coping; Folkman \& Lazarus, 1985). Problem-focused coping is used more in situations

19 that are appraised as changeable, whereas emotion-focused coping occurs in encounters

20 appraised as unchangeable (Folkman \& Lazarus, 1980; Folkman et al., 1986). An example of

21 emotion-focused coping includes escape-avoidance coping where people choose not to focus on

22 the troubling situation. On this, it would be valuable to consider individual coping styles to

23 identify those most vulnerable to and to learn about the mechanisms that promote escape 
1 behaviours. For example, Ferraro et al. (2005) found that a choice between a healthy and

2 unhealthy food following mortality salience was significantly moderated by coping salience;

3 those participants primed with a low coping salience chose the unhealthy option to a significantly

4 greater extent. Likewise, Arndt, Routledge, and Goldenberg (2006) found that people who scored

5 highly on adaptive coping styles were more likely to report healthier behavioural intentions in

6 response to mortality salience. It also seems plausible that people who commonly use avoidant

7 coping strategies (e.g., repression) may be more likely to engage in existential escape than those

8 who do not (e.g., sensitisers who tend to use approach behaviours; Byrne, 1961). That is,

9 individual differences in general coping strategies may qualify escape behaviours and should be

10 investigated more in future research.

11 Practical Implications for Boredom's Existential Escape

By identifying the underlying psychological mechanisms that influence health and social

13 behaviours from an existential escape perspective, important real-world applications can be

14 derived from this research (e.g., Bell \& McBride, 2010; Koball et al., 2012). Indeed, boredom

15 proneness is associated with greater symptom reporting of a variety of physical and

16 psychological health issues (e.g., obsessive-compulsive thoughts, somatisation, interpersonal

17 sensitivity, depression, and anxiety; Sommers \& Vodanovich, 2000). Martin, Sadlo, and Stew

18 (2012) suggested that individual practices or public health programmes might modify some

19 maladaptive, hedonic behaviours initiated to deal with boredom. Indeed, a number of researchers

20 (Chaney \& Burns-Wortham, 2014; Reid, Li, Gilliland, Stein, \& Fong, 2011) suggested that

21 learning alternative coping mechanisms to regulate affect such as boredom may diminish

22 maladaptive, hedonic practices (e.g., sexual acts) and co-morbid meaningless experiences (e.g., 
1 lack of social connectedness, poor self-esteem; Chaney \& Dew, 2003; Reid, Carpenter, \& Lloyd, 2 2009).

In relation, dietary and healthy lifestyle interventions such as implementation intentions

4 were developed to specify where, when, and how to act to obtain health improvement goals (Gollwitzer, 1999), with a particular emphasis on what factors initiate those behaviours, which may include boredom. Increasing evidence shows that implementation intentions are very successful in replacing unhealthy eating and unhealthy behaviours (e.g., Adriaanse, de Ridder, \& de Wit, 2009). Thus, the dynamics of the effects of boredom on unhealthy behaviours as identified in the existential escape literature may hold promise for future intervention designs. More broadly, Mercer-Lynn, Hunter, and Eastwood (2013) found that although trait boredom was associated with hedonic acts such as problem gambling and alcohol abuse, impulsiveness had stronger relationships with these constructs. These researchers suggest that boredom may play a role in the development or exacerbation of variables such as impulsiveness that in turn promote psychosocial problems (Friese \& Hoffman, 2008; see also Dahlen et al., 2005; Stanford et al., 1996; Tice, Bratslavsky, \& Baumeister, 2001). In this regard, Dixon et al., (2014) note that the impulsive nature of gambling (e.g., in slots play), which involves intermittent rewards, may curtail rumination on the self and lead to the underestimation of risk in people's escape activities (e.g., Schüler \& Pfenninger, 2010). Indeed, Dixon et al. found that people at high-risk for gambling problems preferentially endorsed items measuring 'dark flow,' in which attention is focused on the task at hand. Perceived meaninglessness and self-awareness likely play roles if this process takes place as a form of existential escape (Moynihan et al., 2017a). As such, identifying people most prone to boredom, meaninglessness, and to engaging in existential escape (e.g., prompted by impulsiveness) might be beneficial for clinical intervention 
1 (Gerritsen et al., 2014) given the relationship these variables have with constructs that promote

2 potentially harmful means of existential escape and addiction.

\section{$3 \quad$ Long-Term Effectiveness of Escape}

$4 \quad$ Related to these practical applications, engaging in existential escape may be a

5 spontaneous response that serves to address meaninglessness when symbolic mechanisms to

6 regulate meaning are not readily available or if people feel highly incompetent or low in self-

7 esteem to affirm symbolic sources of meaning (e.g., Kesebir \& Pyszczynski, 2012; McGregor et

8 al., 2012). Existential escape may not be functional, however, for long-term adjustments given its

9 potentially harmful consequences (i.e., consumption) and may not solve a problem in the longterm (Wisman et al., 2015). Although hedonic and interpersonal behaviours such as

11 impulsiveness, consumption, and conformity can reduce self-awareness (e.g., Goldenberg et al.,

12 2005; Heatherton \& Baumeister, 1991; Hirschberger \& Ein-Dor, 2005; Wisman \& Koole, 2003),

13 there is a lack of research in the current literature that tests the long-term effectiveness of escape

14 behaviours. Wisman et al. suggest that the effects may only be short-term; thoughts about

15 meaninglessness and self-awareness may rise to consciousness again following escape (Arndt et

16 al., 1997; Elpidorou, 2018a; see also Arndt \& Goldenberg, 2010). Thus, more longitudinal

17 research is required to assess if existential escape defends against meaning threats effectively in

18 the long-term. Indeed, longitudinal research has particular relevance for the practical applications

19 of findings from existential escape research.

In relation, most existential escape studies, with the exception of Wisman et al., (2015) and Wisman and Shrira (2015), did not test whether the dependent measures used actually allows

22 people to escape self-awareness, the facility that highlights the meaninglessness of meaning 
1 behaviours (e.g., Heatherton \& Baumeister, 1991; Twenge et al., 2003), we believe that more

2 research should be conducted in this regard. Interestingly, in one of our pilot studies on boredom

3 and impulsiveness (Moynihan et al., 2017a, Study 3a), we found a significant difference in self-

4 awareness between participants who completed a state self-awareness scale before completing an

5 impulsiveness measure. Those participants in the high boredom condition, associated with more

6 meaninglessness, recorded significantly lower self-awareness than those in the low boredom

7 condition, perhaps indicating people's wishes to escape from adverse self-awareness under

8 boredom. More evidence is required to confirm whether escape actually occurs.

\section{Conclusion}

Boredom is a common, unpleasant experience (Van Tilburg \& Igou, 2012, 2017a). It is a

11 functional emotion since it informs people of the presence of meaninglessness and promotes

12 escape from these situations (Chan et al., 2018; Van Tilburg \& Igou, 2017a; see also Elpidorou,

$132014,2018 \mathrm{a}, 2018 \mathrm{~b}, 2020)$. Previous research on boredom highlighted that boredom promotes

14 the use of symbolic (i.e., cultural) sources of meaning as compensation against this adverse,

15 meaningless experience (e.g., identifying with in-groups, Van Tilburg \& Igou, 2011). We

16 summarised a growing area of research, informed by the existential escape hypothesis (Wisman,

17 2006), suggesting that bored people may also seek to downplay their self-awareness as the

18 inherent meaninglessness of boredom is captured by people's self-awareness (Sedikides \&

19 Skowronski, 1997, 2003). Examples of strategies used to achieve this goal from our research

20 include consumption (Moynihan et al., 2015), impulsiveness (Moynihan et al., 2017a), and other

21 strategies noted in literature on existential processes (e.g., types of conformity, Moynihan et al.,

22 2019; Wisman \& Koole, 2003). In our review, we highlighted the key roles of perceived

23 meaninglessness and adverse self-awareness in these relationships and presented ideas for 
1 alternative means of existential escape that might occur in response to boredom (e.g., sex,

2 conformity, dark flow). Finally, we presented boundary conditions under which the existential

3 escape effects of boredom likely occur (e.g., when bored people have low self-esteem), we

4 discussed the lack of research on the long-term effectiveness of escape as a coping strategy, and

5 we highlighted some practical applications of this field. We believe that appraising and

6 discussing existential escape research on boredom, which to our knowledge has not been

7 conducted previously, provides a thorough and critical synthesis of the present state of research,

8 offering a good outline for future research.

9

10

11

12

13

14

15

16

17

18

19

20

21

22

23 


\section{References}

Adriaanse, M. A., de Ridder, D. T. D., \& de Wit, J. B. F. (2009). Finding the critical cue: Implementation intentions to change one's diet work best when tailored to personally relevant reasons for unhealthy eating. Personality and Social Psychology Bulletin, 35, 60-71. https://doi.org/10.1177/0146167208325612

Alquist, J. L., Ainsworth, S. E., \& Baumeister, R. F. (2013). Determined to conform: Disbelief in free will increases conformity. Journal of Experimental Social Psychology, 49, 80-86. https://doi.org/10.1016/j.jesp.2012.08.015

Arndt, J., \& Goldenberg, J. L. (2010). When self-enhancement drives health-decisions. In M.D. Alicke \& C. Sedikides, (Eds.), Handbook of Self-Enhancement and Self-Protection (pp. 380-398). New York, NY: Guilford Press.

Arndt, J., Greenberg, J., Simon, L., Pyszczynski, T., T., \& Solomon, S. (1998). Terror management and self-awareness: Evidence that mortality salience provokes avoidance of the self-focused state. Personality and Social Psychological Bulletin, 24, 1216-1232. https://doi.org/10.1177/01461672982411008

Arndt, J., Greenberg, J., Solomon, S., Pyszczynski, T., \& Simon, L. (1997). Suppression, accessibility of death-related thoughts, and cultural worldview defense: Exploring the psychodynamics of terror management. Journal of Personality and Social Psychology, 73, 5-18. https://doi.org/10.1037/0022-3514.73.1.5

Arndt, J., Routledge, C., \& Goldenberg, J. L. (2006). Predicting proximal health responses to reminders of death: The influence of coping style and health optimism. Psychology \& Health, 21, 593-614. https://doi.org/10.1080/14768320500537662

Asch, S. E. (1952). Social psychology. Englewood-Cliffs, NJ: Prentice-Hall 
Aspinwall, L. G., \& Taylor, S. E. (1993). Effects of social comparison direction, threat, and selfesteem on affect, self-evaluation, and expected success. Journal of Personality and Social Psychology, 64, 708-722. https://doi.org/10.1037/0022-3514.64.5.708

Aspinwall, L. G., \& Taylor, S. E. (1997). A stitch in time: Self-regulation and proactive coping. Psychological Bulletin, 121, 417-436. https://doi.org/10.1037/0033-2909.121.3.417

Barbalet, J. M. (1999). Boredom and social meaning. British Journal of Sociology, 50, 631-646. https://doi.org/10.1111/j.1468-4446.1999.00631.x

Baumeister, R. F. (1988). Masochism as escape from self. The Journal of Sex Research, 25, 2859. https://doi.org/10.1080/00224498809551444

Baumeister, R. F. (1990). Suicide as escape from self. Psychological Review, 97, 90-113. https://doi.org/10.1037/0033-295X.97.1.90

Baumeister, R. F. (1991). Escaping the self: Alcoholism, spirituality, masochism, and other flights from the burden of selfhood. New York, NY: Basic Books.

Baumeister, R. F., DeWall, C. N., Ciarocco, N. J., \& Twenge, J. M. (2005). Social exclusion impairs self-regulation. Journal of Personality and Social Psychology, 88, 589-604. https://doi.org/10.1037/0022-3514.88.4.589

Bell, C. C., \& McBride, D. F. (2010). Affect regulation and prevention of risky behaviors. The Journal of the American Medical Association, 304, 555-556. https://doi.org/10.1001/jama.2010.1058.

Bench, S. W., \& Lench H. C. (2013). On the function of boredom. Behavioral Sciences, 3, 459472. https://doi.org/10.3390/bs3030459 
1 Bench, S. W., \& Lench, H. C. (2019). Boredom as a seeking state: Boredom prompts the pursuit

of novel (even negative) experiences. Emotion, 19, 242-252. https://doi.org/10.1037/emo0000433

Bergner, R. M., \& Ramon, A. (2013). Some implications of beliefs in altruism, free will, and nonreductionism. Journal of Social Psychology, 153, 598-618. https://doi.org/10.1080/00224545.2013.798249

Bingham, S. A., Welch, A. A., McTaggart, A., Mulligan, A. A., Runswick, S. A., Luben, R., et al. (2001). Nutritional methods in the European prospective investigation of cancer in Norfolk. Public Health Nutrition, 4, 847-858. https://doi.org/10.1079/PHN2000102

Blaszczynski, A., McConaghy, N., \& Frankova, A. (1990). Boredom proneness in pathological gambling. Psychological Reports, 67, 35-42. https://doi.org/10.2466/pr0.1990.67.1.35

Byrne, D. (1961). The repression sensitization scale: Rationale, reliability, and validity. Journal of Personality, 29, 334-349. https://doi.org/10.1111/j.1467-6949.1961.tb01666.x

Carnes, P. J. (2001). Cybersex, courtship, and escalating arousal: Factors in addictive sexual desire. Sexual Addiction \& Compulsivity, 8, 45-78. https://doi.org/10.1080/107201601750259419

Carver, C. S. (1975). Physical aggression as a function of objective self-awareness and attitudes toward punishment. Journal of Experimental Social Psychology, 11, 510-519. https://doi.org/10.1016/0022-1031(75)90002-5

Carver, C. S., \& Scheier, M. F. (1982). Outcome expectancy, locus of attribution for expectancy, and self-directed attention as determinants of evaluations and performance. Journal of Experimental Social Psychology, 18, 184-200. https://doi.org/10.1016/00221031(82)90049-X 
Carver, C. S., Scheier, M. F., \& Weintraub, J. K. (1989). Assessing coping strategies: A theoretically based approach. Journal of Personality and Social Psychology, 56, 267-283. https://doi.org/10.1037/0022-3514.56.2.267

Chan, C. S., Van Tilburg, W. A. P., Igou, E. R., Poon, C. Y. S., Tam, K. Y. Y., Wong, V. U. T., Cheung, S. K. (2018). Situational meaninglessness and state boredom: Cross-sectional and experience sampling findings. Motivation and Emotion, 42, 555-565. https://doi.org/10.1007/s11031-018-9693-3

Chaney, M. P., \& Bialock, A. C. (2006). Boredom proneness, social connectedness, and sexual addiction among men who have sex with male internet users. Journal of Addictions \& Offender Counseling, 26, 111-122. https://doi.org/10.1002/j.2161-1874.2006.tb00012.x

Chaney, M. P., Burns-Wortham, C. M. (2014). The relationship between online sexual compulsivity, dissociation, and past child abuse among men who have sex with men. Journal of LGBT Issues in Counseling, 8, 146-163. https://doi.org/10.1080/15538605.2014.895663

Chaney, M. P., \& Chang, C. Y. (2005). A trio of turmoil for internet sexually addicted men who have sex with men: Boredom proneness, social connectedness, and dissociation. Sexual Addiction \& Compulsivity, 12, 3-18. https://doi.org/10.1080/10720160590933671

Chaney, M. P., \& Dew, B. J. (2003). Online experiences of sexually compulsive men who have sex with men. Sexual Addiction \& Compulsivity, 10, 259-274. https://doi.org/10.1080/10720160390268960

Cleobury, L. \& Tapper, K. (2014). Reasons for eating 'unhealthy' snacks in overweight and obese males and females. Journal of Human Nutrition and Dietetics, 27, 333-341. https://doi.org/10.1111/jhn.12169 
1 Coughlan, G., Igou, E. R., Van Tilburg, W. A. P., Kinsella, E. L., \& Ritchie, T. D. (2019). On boredom and perceptions of heroes: A meaning-regulation approach to heroism. Journal of Humanistic Psychology, 59, 455-473. https://doi.org/10.1177/0022167817705281

Craeynest, M., Crombez, G., Koster, H.W.E., Haerens, L., \& De Bourdeaudhuij. (2008). Cognitive-motivational determinants of fat food consumption in overweight and obese youngsters: The implicit association between fat food and arousal. Journal of Behavior Therapy and Experimental Psychiatry, 39, 354-368. https://doi.org/10.1016/j.jbtep.2007.09.002

Crescioni, A. W., Baumeister, R. F., Ainsworth, S. E., Ent, M., \& Lambert, N. M. (2016). Subjective correlates and consequences of belief in free will. Philosophical Psychology, 29, 41-63. https://doi.org/10.1080/09515089.2014.996285

Crockett, A. C., Myhre, S. K., \& Rokke, P. D. (2015). Boredom proneness and emotion regulation predict emotional eating. Journal of Health Psychology, 20, 570-680. https://doi.org/10.1177/1359105315573439

Csikszentmihalyi, M. (1990). Flow: The psychology of optimal experience. New York, NY: Harper \& Row.

Csikszentmihalyi, M. (2000). Beyond boredom and anxiety: Experiencing flow in work and play. San Francisco: Jossey-Bass.

Csikszentmihalyi, M. (2002). Flow: The classic work on how to achieve happiness. London: Rider.

Csikszentmihalyi, M., Abuhamdeh, S., \& Nakamura, J. (2005). Flow. In A. J. Elliot \& C. S. Dweck (Eds), Handbook of competence and motivation (pp. 598-608). New York, NY: Guilford Publications, Inc 
Dahlen, E. R., Martin, R. C., Ragan, K., \& Kuhlman, M. M. (2004). Boredom proneness in anger and aggression: Effects of impulsiveness and sensation seeking. Personality and Individual Differences, 37, 1615-1627. https://doi.org/10.1016/j.paid.2004.02.016.

Dahlen, E. R., Martin, R. C., Ragan, K., \& Kuhlman, M. M. (2005). Driving anger, sensation seeking, impulsiveness, and boredom proneness in the prediction of unsafe driving. Accident Analysis and Prevention, 37, 341-348. https://doi.org/10.1016/j.aap.2004.10.006

Danckert, J., \& Merrifield, C. (2016). Boredom, sustained attention, and the default mode network. Experimental Brain Research, 236, 2507-2518. https://doi.org/ $10.1007 / \mathrm{s} 00221-016-4617-5$

Dechesne, M., Pyszczynski, T., Arndt, J., Ransom, S., Sheldon, K. M., van Knippenberg, \& Janssen, J. (2003). Literal and symbolic immortality: The effect of evidence of literal immortality on self-esteem striving in response to mortality salience. Journal of Personality and Social Psychology, 84, 722-737. https://doi.org/10.1037/00223514.84.4.722

Diener, E. (1979). Deindividuation, self-awareness, and disinhibition. Journal of Personality and Social Psychology, 37, 1160-1171. https://doi.org/10.1037/0022-3514.37.7.1160

Dixon, M. J., Graydon, C., Harrigan, K. A., Wojtowicz, L., Siu, V., \& Fugelsang, J. A. (2014). The allure of multi-line games in modern slot machines. Addiction, 109, 1920-1928. https://doi.org/10.1111/add.12675

Dixon, M. J., Gutierrez, J., Stange, M., Larche, C. J., Graydon, C., Vintan, S., \& Kruger, T. B. (2019). Mindfulness problems and depression symptoms in everyday life predict dark flow during slots play: Implications for gambling as a form of escape. Psychology of Addictive Behaviors, 33, 81-90. https://doi.org/10.1037/adb0000435 
1 Dixon, M., Stange, M., Larche, C., Graydon, C., Fugelsang, J., \& Harrigan, K. (2017). Dark flow, depression, and multiline slot machine play. Journal of Gambling Studies, 34, 7384. https://doi.org/10.1007/s10899-017-9695-1

Duval, T. S., Duval, V. H., \& Mulilis, J. (1992). Effects of self-focus, discrepancy between self and standard, and outcome expectancy favorability on the tendency to match self to standard or to withdraw. Journal of Personality and Social Psychology, 62, 340-348. https://doi.org/10.1037/0022-3514.62.2.340

Duval, T. S., \& Silvia, P. J. (2002). Self-awareness, probability of improvement, and the selfserving bias. Journal of Personality and Social Psychology, 82, 49-61. https://doi.org/10.1037//0022-3514.82.1.49

Duval, T. S., \& Wicklund, R. A. (1972). A theory of objective self-awareness. New York, NY: Academic Press

Eastwood, J. D., Frischen, A., Fenske, M. J., \& Smilek, D. (2012). The unengaged mind: Defining boredom in terms of attention. Perspectives on Psychological Science, 7, 482495. https://doi.org/10.1177/1745691612456044

Ein-Dor, T., Hirschberger, G., Perry, A., Levin, N., Cohen, R., Horesh, H., \& Rothschild, E. (2014). Implicit death primes increase alcohol consumption. Health Psychology, 33, 748751. https://doi.org/10.1037/a0033880

Elpidorou, A. (2014). The bright side of boredom. Frontiers in Psychology, 5: 1245. https://doi.org/10.3389/fpsyg.2014.01245

Elpidorou, A. (2018a). The good of boredom. Philosophical Psychology, 31, 323-351. https://doi.org/10.1080/09515089.2017.1346240 
1 Elpidorou, A. (2018b). The bored mind is a guiding mind: Toward a regulatory theory of boredom. Phenomenology and the Cognitive Sciences, 17(3), 455-484. https://doi.org/10.1007/s11097-017-9515-1

Elpidorou, A. (2020). Is boredom one or many? A functional solution to the problem of heterogeneity. Mind and Language. https://doi.org/10.1111/mila.12282

Epley, N., \& Gilovich, T., (1999). Just going along: Nonconscious priming and conformity to social pressure. Journal of Experimental Social Psychology, 35, 578-589. https://doi.org/10.1006/jesp.1999.1390

Fahlman, S. A., Mercer, K. B., Gaskovski, P., Eastwood, A. E., \& Eastwood, J. D. (2009). Does a lack of life meaning cause boredom? Results from psychometric, longitudinal, and experimental analyses. Journal of Social and Clinical Psychology, 28, 307-340. https://doi.org/10.1521/jscp.2009.28.3.307

Fahlman, S. A., Mercer-Lynn, K. B., Flora, D. B., \& Eastwood, J. D. (2011). Development and validation of the multi-dimensional boredom scale. Assessment, 20, 68-85. https://doi.org/10.1177/1073191111421303

Fenigstein, A., Scheier, M.F., \& Buss, A.H. (1975). Public and private self-consciousness: Assessment and theory. Journal of Consulting and Clinical Psychology. 43, 522-527. https://doi.org/10.1037/h0076760

Ferraro, R., Shiv, B., Bettman, J.R. (2005). Let us eat and drink for tomorrow we shall die. Effects of mortality salience and self-esteem on self-regulation in consumer choice. Journal of Consumer Research, 32, 65-75. https://doi.org/10.1086/429601 
1 Folkman, S., \& Lazarus, R. S. (1980). An analysis of coping in a middle aged community sample. Journal of Health and Social Behavior, 21, 219-239. https://doi.org/10.2307/2136617

Folkman, S., \& Lazarus, R. S. (1985). If it changes it must be a process: Study of emotion and coping during three stages of a college examination. Journal of Personality and Social Psychology, 48, 150-170. https://doi.org/10.1037/0022-3514.48.1.150

Folkman, S., Lazarus, R. S., Dunkel-Schetter, C., DeLongis, A., \& Gruen, R. J. (1986). Dynamics of a stressful encounter: Cognitive appraisal, coping, and encounter outcomes. Journal of Personality and Social Psychology, 50, 992-1003. https://doi.org/10.1037/0022-3514.50.5.992

Franzoi, S. L., \& Shields, S. A. (1984). The body esteem scale: Multidimensional structure and sex differences in a college population. Journal of Personality Assessment, 48, 173-178. https://doi.org/10.1207/s15327752jpa4802_12

Friese, M., \& Hofmann, W. (2008). What would you have as a last supper? Thoughts about death influence evaluation and consumption of food products. Journal of Experimental Social Psychology, 44, 1388-1394. https://doi.org/10.1016/j.jesp.2008.06.003

Fredrickson, B. L., \& Roberts, T. A. (1997). Objectification theory: An explanation for women's lived experience and mental health risks. Psychology of Women Quarterly, 21, 172-206. https://doi.org/10.1111/j.1471-6402.1997.tb00108.x

Fredrickson, B. L., Roberts, T., Noll, S. M., Quinn, D. M., \& Twenge, J. M. (1998). That swimsuit becomes you: Sex differences in self-objectification, restrained eating, and math performance. Journal of Personality and Social Psychology, 75, 269-284. https://doi.org/10.1037/0022-3514.75.1.269 
1 Gana, K., Trouillet, R., Martin, B., \& Toffart, T., L. (2001). The relationship between boredom proneness and solitary sexual behaviors in adults. Social Behavior \& Personality: An International Journal, 29, 385-389. https://doi.org/10.2224/sbp.2001.29.4.385

Gerritsen, C. J., Toplak, M. E., Sciaraffa, J., \& Eastwood, J. (2014). I can’t get no satisfaction: Potential causes of boredom. Consciousness and Cognition, 27, 27-41. https://doi.org/10.1016/j.concog.2013.10.001

Goldberg, Y. K., Eastwood, J. D., LaGuardia, J., \& Danckert, J. (2011). Boredom: An emotional experience distinct from apathy, anhedonia, or depression. Journal of Social and Clinical Psychology, 30, 647-666. https://doi.org/10.1521/jscp.2011.30.6.647

Goldenberg, J. L., Arndt, J., Hart, J., \& Brown, M. (2005). Dying to be thin: The effects of mortality salience and body mass index on restricted eating among women. Psychology \& Health, 31, 1400-1412. https://doi.org/10.1177/0146167205277207

Goldenberg, J. L., Cox, C. R., Pyszczynski, T., Greenberg, J., \& Solomon, S. (2002). Understanding human ambivalence about sex: The effects of stripping sex of its meaning. The Journal of Sex Research, 39, 310-320. https://doi.org/10.1080/00224490209552155

Goldenberg, J. L., Hart, J., Pyszczynski, T., Warnica, G. M., Landau, M., \& Thomas, L. (2006). Ambivalence toward the body: Death, neuroticism, and the flight from physical sensation. Personality and Social Psychology Bulletin, 32, 1264-1277. https://doi.org/10.1177/0146167206289505

Goldenberg, J. L., Heflick, N. A., \& Cooper, D. P. (2008). The thrust of the problem: Bodily inhibitions and guilt as a function of mortality salience and neuroticism. Journal of Personality, 76, 1055-1080. https://doi.org/10.1111/j.1467-6494.2008.00513.x 
1 Goldenberg, J. L., McCoy, S. K., Pyszczynski, T., Greenberg, J., \& Solomon, S. (2000). The body as a source of self-esteem: The effect of mortality salience on identification with one's body, desire in sex, and appearance monitoring. Journal of Personality and Social Psychology, 79, 118-130. https://doi.org/10.1037/0022-3514.79.1.118

Goldenberg, J. L., Pyszczynski, T., McCoy, S. K., Greenberg, J., \& Solomon, S. (1999). Death, sex, love, and neuroticism: Why is sex such a problem? Journal of Personality and Social Psychology, 77, 1173-1187. https://doi.org/10.1037/0022-3514.77.6.1173

Gollwitzer, P. M. (1999). Implementation intentions: Strong effects of simple plans. American Psychologist, 54, 493-503. https://doi.org/10.1037/0003-066X.54.7.493

Gollwitzer, P. M., \& Wicklund, R. A. (1985). Self-symbolizing and the neglect of others' perspectives. Journal of Personality and Social Psychology, 48, 702-715. https://doi.org/10.1037/0022-3514.48.3.702

Gordon, A., Wilkinson, R., McGrown, A., \& Jovanoska, S. (1997). The psychometric properties of the boredom proneness scale: An examination of its validity. Psychological Studies, 42, 85-97.

Govern, J. M., \& Marsch, L. A. (2001). Development and validation of the situational selfawareness scale. Consciousness and Cognition, 10, 366-378. https://doi.org/10.1006/ccog.2001.0506

Greenberg, J., Arndt, J., Simon, L., Pyszczynski, T., \& Solomon, S. (2000). Proximal and distal defenses in response to reminders of one's mortality: Evidence of a temporal sequence. Personality and Social Psychology Bulletin, 26, 91-99. https://doi.org/10.1177/0146167200261009 
1 Greenberg, J., Pyszczynski, T., \& Solomon, S. (1986). The causes and consequences of a need for self-esteem: A terror management theory. In R.F. Baumeister (Ed.), Public self and private self (pp. 189-212). New York, NY: Springer-Verlag.

Greenberg, J., Pyszczynski, T., \& Solomon, S. (1997). Terror management theory of self-esteem and cultural worldviews: Empirical assessments and conceptual refinements. Advances in Experimental Social Psychology, 29, 61-141. https://doi.org/10.1016/S0065-2601(08)60016-7

Gudjonsson, G. H., \& Sigurdsson, J. F. (2003). The relationship of compliance with coping strategies and self-esteem. European Journal of Psychological Assessment, 19, 117-123. https://doi.org/10.1027//1015-5759.19.2.117

Hamilton, J. A., Haier, R. J., \& Buchsbaum, M. S. (1984). Intrinsic enjoyment and boredom coping scales: Validation with personality, evoked potential and attention measures. Personality and Individual Differences, 5, 183-193. https://doi.org/10.1016/01918869(84)90050-3

Heatherton, T. F., \& Baumeister, R.F. (1991). Binge eating as escape from self-awareness. Psychological Bulletin, 110, 86-108. https://doi.org/10.1037/0033-2909.110.1.86

Heatherton, T. F, Herman, C. P., \& Polivy, J. (1991). Effects of physical threat and ego threat on eating behavior. Journal of Personality and Social Psychology, 60. 138-143. https://doi.org/10.1037/0022-3514.60.1.138

Heatherton, T. F., Polivy, J., Herman, C. P., \& Baumeister, R. F. (1993). Self-awareness, task failure and disinhibition: How attentional focus affects eating. Journal of Personality, 61, 49-61. https://doi.org/10.1111/1467-6494.ep9303190327 
1 Heatherton, T. F., Striepe, M., \& Wittenberg, L. (1998). Emotional distress and disinhibited eating: The role of the self. Personality and Social Psychology Bulletin, 24, 301-313. https://doi.org/10.1177/0146167298243007

Heine, S. J., Proulx, T., \& Vohs, K. D. (2006). The meaning maintenance model: On the coherence of social motivations. Personality and Social Psychology Review, 10, 88-110. https://doi.org/10.1207/s15327957pspr1002_1

Hirschberger, G., \& Ein-Dor, T. (2005). Does a candy a day keep the death thoughts away? The terror management function of eating. Basic \& Applied Social Psychology, 27, 179-186. https://doi.org/10.1207/s15324834basp2702_9

Hull, J.G. (1981). A self-awareness model of the causes and effects of alcohol consumption. Journal of Abnormal Psychology, 90, 586-600. https://doi.org/10.1037/0021843X.90.6.586

Hunter, A., \& Eastwood, J. D. (2018). Does state boredom cause failures of attention? Examining the relations between trait boredom, state boredom, and sustained attention. Experimental Brain Research, 236, 2483-2492. https://doi.org/10.1007/s00221-0164749-7

Karpinski, A., \& Steinman, R. B. (2006). The single category implicit association test as a measure of implicit social cognition. Journal of Personality and Social Psychology, 91, 16-32. https://doi.org/10.1037/0022-3514.91.1.16

Kass, S. J., Beede, K. E., \& Vodanovich, S. J. (2010). Self-report measures of distractibility as correlates of simulated driving performance. Accident Analysis \& Prevention, 42, 874880. https://doi.org/10.1016/j.aap.2009.04.012 
Kass, S. J., \& Vodanovich, S. J. (1990). Boredom proneness: Its relationship to type A behavior pattern and sensation seeking. Psychology: A Journal of Human Behavior, 27, 7-16.

Kesebir, P., \& Pyszczynski, T. (2012). The role of death in life: Existential aspects of human motivation. In R.M. Ryan (Ed.), The Oxford handbook of human motivation (pp. 43-64). New York, NY: Oxford University Press.

Kılıç, A., Van Tilburg, W. A. P., Igou, E. R. (2020). Risk-taking increases under boredom. Journal of Behavioral Decision-Making, 33, 257-269. https://doi.org/10.1002/bdm.2160

Kim, J., Seto, E., Davis, W. E., \& Hicks, J. A. (2015). Positive and existential psychological approaches to the experience of meaning in life. In A. Batthyany \& P. Russo-Netzer (Eds)., Meaning in positive and existential psychology (pp.221-233). New York, NY: Springer.

Koball, A. M., Meers, M. R., Storfer-Isser, A., Domoff, S. E., \& Musher-Eizenman, D. R. (2012). Eating when bored: Revision of the Emotional Eating Scale with a focus on boredom. Health Psychology, 31, 521-524. https://doi.org/10.1037/a0025893

Koole, S. L., Sin, M. T. A., \& Schneider, I. K. (2014). Embodied terror management: Interpersonal touch alleviates existential concerns among individuals with low selfesteem. Psychological Science, 25, 30-37. https://doi.org/10.1177/0956797613483478

Landau, M. J., \& Greenberg, J. (2006). Play it safe or go for the gold? A terror management perspective on self-enhancement and self-protective motives in risky decision making. Personality and Social Psychology Bulletin, 32, 1633-1645. https://doi.org/ 10.1177/0146167206292017 
1 Landau, M. J., Goldenberg, J. L., Greenberg, J., Gillath, O., Solomon, S., Cox, C., \& ... Pyszczynski, T. (2006). The siren's call: Terror management and the threat of men's sexual attraction to women. Journal of Personality and Social Psychology, 90, 129-146. https://doi.org/10.1037/0022-3514.90.1.129

Leary, M. R., Rogers, P. A., Canfield, R. W., \& Coe, C. (1986). Boredom in interpersonal encounters: Antecedents and social implications. Journal of Personality and Social Psychology, 51, 968-975. https://doi.org/10.1037/0022-3514.51.5.968

Lee, C. M., Neighbors, C., \& Woods, B. A. (2007). Marijuana motives: Young adults' reasons for using marijuana. Addictive Behaviours, 32, 1384-1394. https://doi.org/10.1016/j.addbeh.2006.09.010

Leong, F. T. L. \& Schneller, G. R. (1993). Boredom proneness: Temperamental and cognitive components. Personality and Individual Differences, 14, 233-239. https://doi.org/10.1016/0191-8869(93)90193-7

Lynn, M. T., Muhle-Karbe, P. S., Aarts, H., \& Brass, M. (2014). Priming determinist beliefs diminishes implicit (but not explicit) components of self-agency. Frontiers in Psychology, 5: 1483. https://doi.org/10.3389/fpsyg.2014.01483

Lynn, M. T., Van Dessel, P., \& Brass, M. (2013). The influence of high-level beliefs on selfregulatory engagement: Evidence from thermal pain stimulation. Frontiers in Psychology, 4: 614. https://doi.org/10.3389/fpsyg.2013.00614

Martin, M., Sadlo, G., \& Stew, G. (2012). Rethinking occupation deprivation and boredom. Journal of Occupational Science, 19, 54-61. https://doi.org/10.1080/14427591.2011.640210 
McGuire, M., \& Beerman, K.A. (2007). Nutritional sciences: From fundamentals to food. Belmont, CA: Thompson Wadsworth Publishers.

McGregor, I., Nash, K. A., Prentice, M., Hirsh, J., \& Inzlicht, M. (2012). Raw data. Toronto, Canada: York University.

Mercer, K. B., \& Eastwood, J. D. (2010). Is boredom associated with problem gambling behaviour? It depends on what you mean by boredom. International Gambling Studies, 10, 91-104. https://doi.org/10.1080/14459791003754414

Mercer-Lynn, K. B., Flora, D. B., Fahlman, S. A., \& Eastwood, J. D. (2013). The measurement of boredom: Differences between existing self-report scales. Assessment, 20, 585-596. https://doi.org/10.1177/1073191111408229

Mercer-Lynn, K. B., Hunter, J. A., \& Eastwood, J., D. (2013). Is trait boredom redundant? Journal of Social and Clinical Psychology, 32, 897-916. https://doi.org/10.1521/jscp.2013.32.8.897

Merrifield, C., \& Danckert, J. (2014). Characterizing the psychophysiological signature of boredom. Experimental Brain Research, 232, 481-491. https://doi.org/10.1007/s00221$013-3755-2$

Mikulas, W., \& Vodanovich, S. (1993). The essence of boredom. Psychological Record, 43, 312.

Moynihan, A. B., Igou, E. R., \& Van Tilburg, W. A. P. (2017a). Boredom increases impulsiveness: A meaning-regulation perspective. Social Psychology, 48, 293-309. https://doi.org/10.1027/1864-9335/a000317 
Moynihan, A. B., Igou, E. R., \& Van Tilburg, W. A. P. (2017b). Free, connected, and meaningful: Free will belief promotes meaningfulness through belongingness. Personality and Individual Differences, 107, 54-65. https://doi.org/10.1016/j.paid.2016.11.006

Moynihan, A. B., Igou, E. R., \& Van Tilburg, W. A. P. (2017c). [The impact of boredom and self-awareness on unhealthy behaviours at levels of self-objectification]. Unpublished raw data.

Moynihan, A. B., Igou, E. R., Van Tilburg, W. A. P., (2017d). [The impact of boredom and selfawareness on consumption at levels of body-esteem]. Unpublished raw data.

Moynihan, A. B., Igou, E. R., \& Van Tilburg W. A. P. (2019). Lost in the crowd: Conformity as escape following disbelief in free will. European Journal of Social Psychology, 43, 509-520. https://doi.org/10.1002/ejsp.2499

Moynihan, A. B., Igou, E. R., \& Van Tilburg W. A. P. (2021). Bored stiff: The relationship between meaninglessness, sexual sensation seeking, and promiscuous attitudes via boredom susceptibility. Personality and Individual Differences. https://doi.org/10.1016/j.paid.2020.110295

Moynihan, A. B., Van Tilburg, W. A. P., Igou. E. R., Wisman, A., Donnelly, A. E., \& Mulcaire, J. (2015). Eaten up by boredom: Consuming food to escape awareness of the bored self. Frontiers in Psychology, 6: 369. https://doi.org/10.3389/fpsyg.2015.00369

Mullen, B. (1991). Group composition, salience, and cognitive representations: The phenomenology of being in a group. Journal of Experimental Social Psychology, 27, 297-323. https://doi.org/10.1016/0022-1031(91)90028-5 
1 Nasser, J. A., Gluck, M. E., \& Geliebter, A. (2004). Impulsivity and test meal intake in obese binge eating women. Appetite, 43, 303-307. https://doi.org/10.1016/j.appet.2004.04.006

Partington, S., Partington, E., \& Olivier, S. (2009). The dark side of flow: a qualitative study on

4 dependence in big wave surfing. The Sport Psychologist, 23, 170-185. https://doi.org/10.1123/tsp.23.2.170

Patton, J. H., Stanford, M. S., \& Barratt, E. S. (1995). Factor structure of the Barrett impulsiveness scale. Journal of Clinical Psychology, 51, 768-774. https://doi.org/10.1002/1097-4679(199511)51:6<768::AID-JCLP2270510607>3.0.CO;21

Paul, B., \& Shim, J. W. (2008). Gender, sexual affect, and motivations for internet pornography use. International Journal of Sexual Health, 20, 187-199. https://doi.org/10.1080/19317610802240154

Phillips, A. G., \& Silvia, P. J. (2005). Self-awareness and the emotional consequences of selfdiscrepancies. Personality and Social Psychology Bulletin, 31, 703-713. https://doi.org/10.1177/0146167204271559

Polivy, H., Heatherton, T. F., \& Herman, C. P. (1988). Self-esteem, restraint, and eating behavior. Journal of Abnormal Psychology, 97, 354-356. https://doi.org/10.1037/0021843X.97.3.354

Pyszczynski, T., Greenberg, J., \& Solomon, S. (1999). A dual-process model of defense against conscious and unconscious death-related thoughts: An extension of terror management theory. Psychological Review, 106, 835-845. https://doi.org/10.1037/0033295X.106.4.835 
1 Reed, M. B., \& Aspinwall, L. G. (1998). Self-affirmation reduces biased processing of healthrisk information. Motivation and Emotion, 22, 99-132. https://doi.org/10.1023/A:1021463221281

Reid, R. C., Carpenter, B. N., \& Lloyd, T. Q. (2009). Assessing psychological symptom patterns of patients seeking help for hypersexual behavior. Sexual and Relationship Therapy, 24, 47-63. https://doi.org/10.1080/14681990802702141

Reid, R. C., Carpenter, B. N., Spackman, M., \& Willes, D. L. (2008). Alexithymia, emotional instability, and vulnerability to stress proneness in patients seeking help for hypersexual behavior. Journal of Sex \& Marital Therapy, 34, 133-149. https://doi.org/10.1080/00926230701636197

Reid, R. C., Harper, J. M., \& Anderson, E. H. (2009). Coping strategies used by hypersexual patients to defend against the painful effects of shame. Clinical Psychology \& Psychotherapy, 16, 125-138. https://doi.org/10.1002/cpp.609

Reid, R. C., Li, D. S., Gilliland, R., Stein, J. A., \& Fong, T. (2011). Reliability, validity, and psychometric development of the pornography consumption inventory in a sample of hypersexual men. Journal of Sex and Marital Therapy, 37, 359-385. https://doi.org/10.1080/0092623X.2011.607047

Rigoni, D., Kuhn, S., Sartori, G., \& Brass, M. (2011). Inducing disbelief in free will alters brain correlates of preconscious motor preparation: The brain minds whether we believe in free will or not. Psychological Science, 22, 613-618. https://doi.org/10.1177/0956797611405680 
1 Rigoni, D., Pourtois, G., \& Brass, M. (2015). "Why should I care?” Challenging free will attenuates neural reaction to errors. Social Cognitive and Affective Neuroscience, 10, 262-268. https://doi.org/10.1093/scan/nsu068

Rupp, D., \& Vodanovich, S. J. (1997). The role of boredom proneness in self-reported anger and aggression. Journal of Social Behavior and Personality, 12, 925-936. https://doi.org/10.1016/j.paid.2004.02.016

Schüler, J., \& Nakamura, J. (2013). Does flow experience lead to risk? How and for whom. Applied Psychology: Health and Well-Being, 5, 311-331. https://doi.org/10.1111/aphw.12012

Schüler, J. \& Pfenninger, M. (2010). Flow impairs risk perception in kayakers. In B. D. Geranto (Ed.), Sport psychology (pp. 1-11). New York, NY: Nova Science Publishers.

Sedikides, C., \& Skowronski, J. J. (1997). The symbolic self in evolutionary context. Personality and Social Psychology Review, 1, 80-102. https://doi.org/10.1207/s15327957pspr0101_6

Sedikides, C., \& Skowronski, J. J. (2003). Evolution of the self: Issues and prospects. In M. R. Leary \& J. P. Tangney (Eds.), Handbook of self and identity (pp. 594-609). New York, NY: Guilford.

Seib, H. M., \& Vodanovich, S. J. (1998). Cognitive correlates of boredom proneness: The role of private self-consciousness and absorption. Journal of Psychology, 132, 642-652. https://doi.org/10.1080/00223989809599295

Silvia, P. J. (2001). Nothing or the opposite: Intersecting terror management and objective selfawareness. European Journal of Personality, 15, 73-82. https://doi.org/10.1002/per.399| 
Silvia, P. J., \& Duval, T. S. (2001). Objective self-awareness theory: Recent progress and enduring problems. Personality and Social Psychology Review, 5, 230-241. https://doi.org/10.1207/S15327957PSPR0503_4

Skowronski, J. J., \& Sedikides, C. (2019). On the evolution of the human self: A data-driven review and reconsideration. Self and Identity, 18, 4-21. https://doi.org/10.1080/15298868.2017.1350601

Sommers, J., \& Vodanovich, S. J. (2000). Boredom proneness: Its relationship to psychologicaland physical-health symptoms. Journal of Clinical Psychology, 56, 149-155. https://doi.org/10.1002/(SICI)1097-4679(200001)56:1<149::AID-JCLP14>3.0.CO;2-Y

Stanford, M. S., Greve, K. W., Boudreaux, J. K., Mathias, C. W., \& Brumbelow, J. L. (1996). Impulsiveness and risk-taking behavior: Comparison of high-school and college students using the Barrett impulsiveness scale. Personality and Individual Differences, 21, 10731075. https://doi.org/10.1016/S0191-8869(96)00151-1

Stanford, M. S., Mathias, C. W., Dougherty, D. M., Lake, S. L., Anderson, N. E., \& Patton, J. H. (2009). Fifty years of the Barrett Impulsiveness Scale: An update and review. Personality and Individual Differences, 47, 385-395. https://doi.org/10.1016/j.paid.2009.04.008

Stickney, M. I., \& Miltenberger, R. G. (1999). Evaluating direct and indirect measures for the functional assessment of binge eating. International Journal of Eating Disorders, 26, 195-204. https://doi.org/10.1002/(SICI)1098-108X(199909)26:2<195::AID-

\section{EAT9>3.0.CO;2-2}

Tai, K., Zheng, X., \& Narayanan, J. (2011). Touching a teddy bear mitigates negative effects of social exclusion to increase prosocial behavior. Social Psychological \& Personality Science, 2, 618-626. https://doi.org/10.1177/1948550611404707 
Taubman Ben-Ari, O. (2004). Intimacy and risky sexual behavior-What does it have to do with death? Death Studies, 28, 865-887. https://doi.org/10.1080/07481180490490988

Taubman Ben-Ari, O., \& Findler, L. (2005). Proximal and distal effects of mortality salience on willingness to engage in health promoting behavior along the life span. Psychology \& Health, 20, 303-318. https://doi.org/10.1080/08870440512331317661

Taubman Ben-Ari, O., Florian, V., \& Mikulincer, M. (1999). The impact of mortality salience on reckless driving: A test of terror management mechanisms. Journal of Personality and Social Psychology, 76, 35-45. https://doi.org/10.1037/0022-3514.76.1.35

Taubman Ben-Ari, O., \& Noy, A. (2010). Self-consciousness and death cognitions from a terror management perspective. Death Studies, 34, 871-892. https://doi.org/10.1080/07481187.2010.496685

Tetlock, P. E. (1983). Accountability and complexity of thought. Journal of Personality and Social Psychology, 45, 74-83. https://doi.org/10.1037/0022-3514.45.1.74

Tetlock, P. E., Skitka, L., \& Boettger, R. (1989). Social and cognitive strategies for coping with accountability: Conformity, complexity, and bolstering. Journal of Personality and Social Psychology, 57, 632-640. https://doi.org/10.1037/0022-3514.57.4.632

Tice, D. M., Bratslavsky, E., \& Baumeister, R. F. (2001). Emotional distress regulation takes precedence over impulse control: If you feel bad, do it! Journal of Personality and Social Psychology, 80, 53-67. https://doi.org/10.1037/0022-3514.80.1.53

Twenge, J. M., Catanese, K. R., \& Baumeister, R. F. (2003). Social exclusion and the deconstructed state: Time perception, meaninglessness, lethargy, lack of emotion, and self-awareness. Journal of Personality and Social Psychology, 85, 409-423. https://doi.org/10.1037/0022-3514.85.3.409 
Van Tilburg, W. A. P., \& Igou, E. R. (2011). On boredom and social identity: A pragmatic meaning-regulation approach. Personality and Social Psychology Bulletin, 37, 16791691. https://doi.org/10.1177/0146167211418530

Van Tilburg, W. A. P., \& Igou, E. R. (2012). On boredom: Lack of challenge and meaning as distinct boredom experiences. Motivation and Emotion, 36, 181-194. https://doi.org/10.1007/s11031-011-9234-9

Van Tilburg, W. A. P., \& Igou, E. R. (2013). On the meaningfulness of behavior: An expectancy x value approach. Motivation and Emotion, 37, 373-388. https://doi.org/10.1007/s11031012-9316-3

Van Tilburg, W. A. P., \& Igou, E. R. (2016). Going to political extremes in response to boredom. European Journal of Social Psychology, 46, 687-699. https://doi.org/10.1002/ejsp.2205

Van Tilburg, W. A. P., \& Igou, E. R. (2017a). Boredom begs to differ: Differentiation from other negative emotions. Emotion, 17, 309-322. https://doi.org/10.1037/emo0000233

Van Tilburg, W. A. P., \& Igou, E. R. (2017b). Can boredom help? Increased prosocial intentions in response to boredom. Self and Identity, 16, 82-96. https://doi.org/10.1080/15298868.2016.1218925

Van Tilburg, W. A. P., Igou, E. R., Maher, P. J., \& Lennon, J. (2019). Various forms of existential distress are associated with aggressive tendencies. Personality and Individual Differences, 144, 111-119. https://doi.org/10.1016/j.paid.2019.02.032

Van Tilburg, W. A. P., Igou, E. R., Maher, P. J., Moynihan, A. B., \& Martin, A. (2019). Bored like hell: Religiosity reduces boredom and tempers the quest for meaning. Emotion, 19, 255-269. https://doi.org/10.1037/emo0000439 
Van Tilburg, W. A. P., Igou, E. R., \& Sedikides, C. (2013). In search of meaningfulness: Using nostalgia as an antidote to boredom. Emotion, 13, 450-461. https://doi.org/10.1037/a0030442

Watson, D., Clark, L. A., \& Tellegen, A. (1988). Development and validation of brief measures of positive and negative affect: The PANAS scales. Journal of Personality and Social Psychology, 54, 1063-1070. https://doi.org/10.1037/0022-3514.54.6.1063

Watt, J. D., \& Vodanovich, S. J. (1992). Relationship between boredom proneness and impulsivity. Psychological Reports, 70, 688-690. https://doi.org/10.2466/pr0.1992.70.3.688

Wheeler, H. A., Adams, G. R., \& Keating, L. (2001). Binge eating as a means for evading identity issues: The association between an avoidance identity style and bulimic behaviour. Identity: An International Journal of Theory and Research, 1, 161-178. https://doi.org/10.1207/S1532706XID0102_04

Wicklund, R., \& Duval, S. (1971). Opinion change and performance facilitation as a result of objective self-awareness. Journal of Experimental Social Psychology, 7, 319-342. https://doi.org/10.1016/0022-1031(71)90032-1

Wisman, A. (2006). Digging in terror management theory: To 'use' or 'lose' the symbolic self? Psychological Inquiry, 17, 319-327. https://doi.org/10.1080/10478400701369468

Wisman, A., \& Koole, S. L. (2003). Hiding in the crowd: Can mortality salience promote affiliation with others who oppose one's worldviews? Journal of Personality and Social Psychology, 84, 511-526. https://doi.org/10.1037/0022-3514.84.3.511 
1 Wisman, A., Heflick, N., \& Goldenberg, J. L. (2015). The great escape: The role of self-esteem and self-related cognition in terror management. Journal of Experimental Social Psychology, 60, 121-132. https://doi.org/10.1016/j.jesp.2015.05.006

4 Wisman, A., \& Goldenberg, J. (2005). From the grave to the cradle: Evidence that mortality salience engenders a desire for offspring. Journal of Personality \& Social Psychology, 89, 46-61. https://doi.org/10.1037/0022-3514.89.1.46

7 Wisman, A., \& Shrira, I. (2006). The terror of belongingness: Evidence that mortality salience promotes defensive affiliation. Poster presentation at the annual meeting of the Society for Personality and Social Psychology, Palm Springs, CA, United States.

Wisman, A., \& Shrira, I. (2015). The smell of death: Evidence that putrescine elicits threat management mechanisms: The smell of death. Frontiers in Psychology, 6: 1274, 1-26. https://doi.org/10.3389/fpsyg.2015.01274

13 Zimbardo, P. G. (2007). The Lucifer effect. New York, NY: Random House. 